
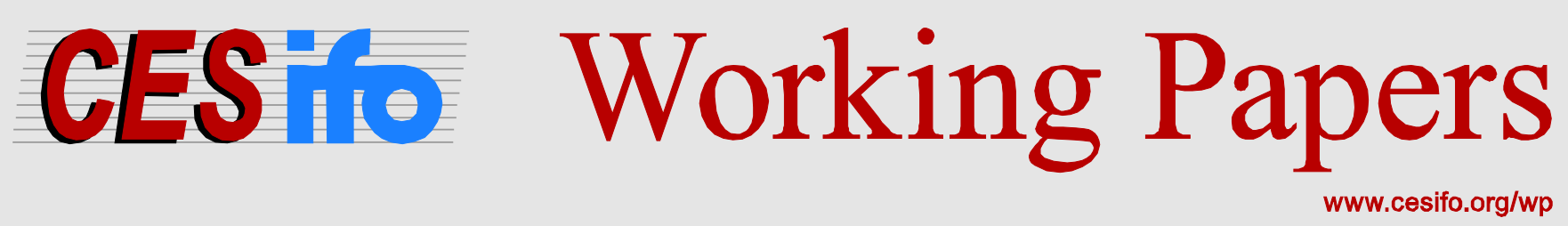

\title{
China's Exchange Rate and Financial Repression: The Conflicted Emergence of the Renminbi as an International Currency
}

\author{
Ronald McKinnon \\ Gunther Schnabl
}

\author{
CESIFO WORKING PAPER NO. 4649 \\ CATEGORY 7: MONETARY POLICY AND INTERNATIONAL FinANCE \\ FEBRUARY 2014
}
An electronic version of the paper may be downloaded
- from the SSRN website: Www.SSRN.com
- from the RePEc website: Www.RePEc.org
- from the CESifo website: www.CESifo-group.org/wp

\section{CESifo}




\title{
China’s Exchange Rate and Financial Repression: The Conflicted Emergence of the Renminbi as an International Currency
}

\begin{abstract}
China has been provoked into speeding renmnibi internationalization. But despite rapid growth in offshore financial markets in RMB, the Chinese authorities are essentially trapped into maintaining exchange controls-reinforced by financial repression in domestic interest rates - to avoid an avalanche of foreign capital inflows that would threaten inflation and asset price bubbles by driving nominal interest rates on RMB assets down further. Because a floating (appreciating) exchange rate could attract even more hot money inflows, the People's Bank of China should focus on tightly stabilizing the yuan/ dollar exchange rate to encourage naturally high wage increases for balancing China's international competitiveness.
\end{abstract}

JEL-Code: F150, F310, F330.

Keywords: China, informal dollar standard, internationalization of renminbi, exchange rate stabilization, inflation, financial repression.

\author{
Ronald McKinnon \\ Economics Department \\ Stanford University \\ USA - Stanford, California 94305-6072 \\ mckinnon@stanford.edu
}

\author{
Gunther Schnabl \\ Leipzig University \\ Institute of Economic Policy \\ Grimmaische Str. 12 \\ Germany - 04109 Leipzig \\ schnabl@wifa.uni-leipzig.de
}

February 2014

We thank Stefan Angrick, Raphael Fischer and Zhao Liu for excellent research assistance. 


\section{Introduction}

Despite past and present global monetary turmoil emanating from the United States, with policies of zero short-term interest rates and longer term quantitative easing expected to continue, the world (outside of Europe) is still on a dollar standard [McKinnon 2013]. In East Asia, international trade-including the burgeoning intra-industry trade within the region-is mainly invoiced in dollars. The dollar remains the dominant means of settlement for international payments among banks, and is the principal intervention currency used by governments, such as China's, for smoothing exchange rate fluctuations.

Because other countries choose to peg, or at least smooth their exchange rates against the dollar, the United States does not have any direct exchange rate policy of its own. The U.S. government holds hardly any official foreign reserves and rarely intervenes in foreign exchange markets. This passivity is critical to the smooth functioning of the international dollar standard because it avoids direct conflict between foreign central banks in setting their exchange rates. Once any one country, say China, targets 6.1 yuan/dollar, and other countries in Asia and Latin America also set their exchange rates against the dollar, triangular arbitrage determines the whole structure of cross rates - spot and forward - between any pair of non-dollar currencies as long as the U.S. bond markets remain open to foreigners to transact freely at all terms to maturity [McKinnon 1979]. By abstaining from official intervention, the United States - at the center of the world dollar standard - facilitates multilateral exchange. By intervening only in dollars, foreign central banks avoid intervening at cross-purposes with each other.

Despite global pressure to make the Chinese renminbi more flexible and to let it appreciate against the dollar, sometimes called "China bashing", the People's Bank of China (PBC) has mostly kept the renminbi stable against the dollar since 1994, when the domestic system of multiple exchange rates was unified at 8.28 yuan per dollar. True, the renminbi was allowed to gradually appreciate against the dollar from July 2005 to July 2008 and since 2010; but over the past 20 years until the present rate of 6.1 yuan/dollar in early 2014, the PBC has kept China's dollar exchange rate remarkably stable in comparison to other East Asian and emerging market (EM) currencies. 
Since 2000, however, China bashing to let the RMB appreciate against the dollar—ostensibly to reduce China's current account surplus-has persisted [Cline and Williamson 2012 and Bergsten 2013]. But full exchange rate flexibility is only possible if the RMB is fully convertible and backed by large and developed financial markets [McKinnon and Schnabl 2004]. Demands to make the RMB more flexible have been paired with demands to liberalize the Chinese capital market both nationally and internationally [Ito 2011, Ballantyne et al. 2013, Prasad and Ye 2012]. Indeed, the role of the RMB in rapidly growing offshore financial markets [Craig et al. 2013], and bilateral swap agreements with a growing number of central banks, has promoted a still-modest use of the RMB in China's border trade.

However, with near-zero short-term interest rates and persistent quantitative easing at long term in the U.S. and other large industrial countries - combined with underdeveloped Chinese capital markets - China is well advised to keep the renminbi tightly pegged to the dollar. We shall also show that China should also maintain tight capital controls to avoid further hot money inflows that threaten exchange appreciation and a loss of monetary control by the People's Bank of China, which would lead to general inflation and further upward pressure on property prices.

For comparison, on page 6, we draw on Japan's experience more than 30 years ago with international pressure to appreciate the yen to reduce Japan's trade surplus versus the U.S."Japan bashing". What were the repercussions on goods and financial markets of massive yen appreciations from 360 yen/dollar in 1971 to 80 yen/dollar by 1995? We argue that, given China's role of an immature international creditor today, exchange rate stability against the dollar, exchange controls on financial inflows, and some repression in interest rates on RMB assets is a better choice than full financial liberalization. Rapid increases in Chinese wages at a stable yuan/dollar rate then become the natural variable for balancing international competitiveness without inducing more hot money flows from expected exchange appreciation. 


\section{The Exchange Rate as a Contested Stabilizer}

Since 1994, China's fixed dollar exchange rate has been the basis for an impressive economic catch-up driven by foreign direct investment and rapid export expansion. Multinational firms set up production platforms in China for sales - mainly invoiced in dollars — on a worldwide basis. The sheer magnitude of this export success was bound to awaken a protectionist reaction in the more mature industrial countries in North America, Europe, and Japan. But, under Premier Zhu Rongji, China joined the World Trade Organization (WTO) in 2001. Thus foreign member countries could not mount direct protectionist strategies using tariffs or quotas to restrict imports from China - unlike how they threatened Japan three decades ago. Although antidumping duties on Chinese imports are legal under the WTO, these procedures are sufficiently complex that they restrain protectionists. Compared to the earlier experience of Japan, multinational firms are more reluctant to file dumping suits against imports from China if only because they have Chinese manufacturing facilities of their own.

Therefore, foreign governments, led by the U.S., have focused more on the yuan/dollar rate as the principal tool to contain Chinese exports. They claim that the renminbi has been deliberately kept undervalued to give Chinese exports an unfair mercantile advantage - the essence of socalled China bashing. The WTO is silent on exchange rate practices, and the IMF's revised articles of agreement are now ambiguous. But in the face of large trade surpluses over the past decade, China's pegged dollar exchange rate has remained controversial despite the recent gradual appreciation path. There are two issues concerning the impact of the yuan/dollar exchange rate on China's trade balance.

The first issue is analytical: the belief that a country's exchange rate can — and possibly shouldbe "assigned" to controlling its net trade balance [Meade 1951]. To correct any "imbalance", countries with a net trade deficit should depreciate, and countries with a net trade surplus, should appreciate. Because the U.S. does not have any direct exchange rate policy of its own, it applies political pressure on countries with trade surpluses to appreciate. 
But what might have been a correct argument in Meade's era of the 1950s, when economies were more insular - both in terms of limited commodity trade and more restricted capital flows - is no longer valid in a globalized world where trade in goods and capital flow much more freely [Qiao 2007]. In today's more liberalized environment, consider a large creditor country like China with huge domestic saving (about 50 percent of GDP) that finances both a large trade surplus and very large domestic investment (about 45 percent of GDP. The standard accounting identity for the current account balance is

$$
\mathrm{X}-\mathrm{M}=\mathrm{S}-\mathrm{I}
$$

where $\mathrm{X}$ is exports, $\mathrm{M}$ is imports, $\mathrm{S}$ is saving, and $\mathrm{I}$ is domestic investment. If one focuses just on the left hand side of equation (1), a substantial appreciation of the RMB would seem to reduce exports as they become more expensive to foreign buyers, while imports increase because they become cheaper in domestic currency. Exports should fall and imports should rise: China's trade (current account) surplus would seem to decline even if the export and import price elasticities are only moderately large. In a world of insular economies, domestic saving and investment are not directly affected by exchange rate changes. Thus the older academic literature based on the so-called "elasticities model of the balance of trade" presumes that China's trade surplus should decline if the RMB appreciates.

In contrast, in the modern globalized world economy, firms are multinational and countries compete with each other to attract investments. Assume that domestic saving is more or less given independently of the exchange rate, which seems to be approximately true empirically. Then, focusing on the right-hand side of (1), a newly appreciated renminbi would turn China into a more expensive place for international investors, so that domestic investment would slump [McKinnon 2013: ch. 8]. S - I could rise and China's trade surplus actually increase from exchange appreciation! In addition, insofar as the private sector in China is a substantial holder of net dollar assets, there will also be a negative wealth effect on consumption as the renminbi value of these dollar assets declines [Qiao 2007]. The total effect on China's net trade balance of any discrete appreciation of the renminbi is thus ambiguous: Exports fall but so do imports, because of the negative investment and consumption effects on income. 


\section{a. Japan Bashing: A Potted History}

Japan provides a natural experiment to assess the impact of a strong exchange rate appreciation on the trade balance. More than 30 years ago, with Japan liberalizing international capital flows and the U.S. pursuing a policy mix of tight monetary policy (under the new Fed chairman Paul Volcker) and expansionary fiscal policy (under the new president Ronald Reagan), the U.S. attracted rising net capital inflows from Japan. In the early 1980s, the dollar appreciated against the yen, and U.S. capital inflows were matched by a fast rising U.S. current account deficitmainly with Japan (figure 1). Because the surge of Japanese exports to the U.S. was accompanied by accelerating deindustrialization in the U.S., particularly in the automobile and electronics industries, Japan bashing emerged. Japan was blamed for unfair trade practices, which were claimed to cause painful losses of jobs in the U.S. industrial sector [McKinnon and Ohno 1997].

The principal U.S. policy response was to impose political pressure on Japan to appreciate the yen. In September 1985 at the Plaza Hotel in New York, an exchange-rate agreement triggered the yen to appreciate more than 50 percent against the dollar. This appreciation slowed Japanese exports and GDP growth but did not achieve the intended reduction of Japan's trade surplus. Instead, Japan's current account surplus further increased, as Japanese export enterprises cut prices (production costs) and invested more abroad. Slower and even negative GDP growth reduced imports more than exports [Qiao 2007]. Only following the Louvre Accord (February 1987), after the Bank of Japan had slashed interest rates to slow the yen appreciation paired with an expansionary fiscal policy, did the Japanese trade surplus decline moderately [Schnabl 2013]. 
Figure 1: US-East Asian Trade Imbalances

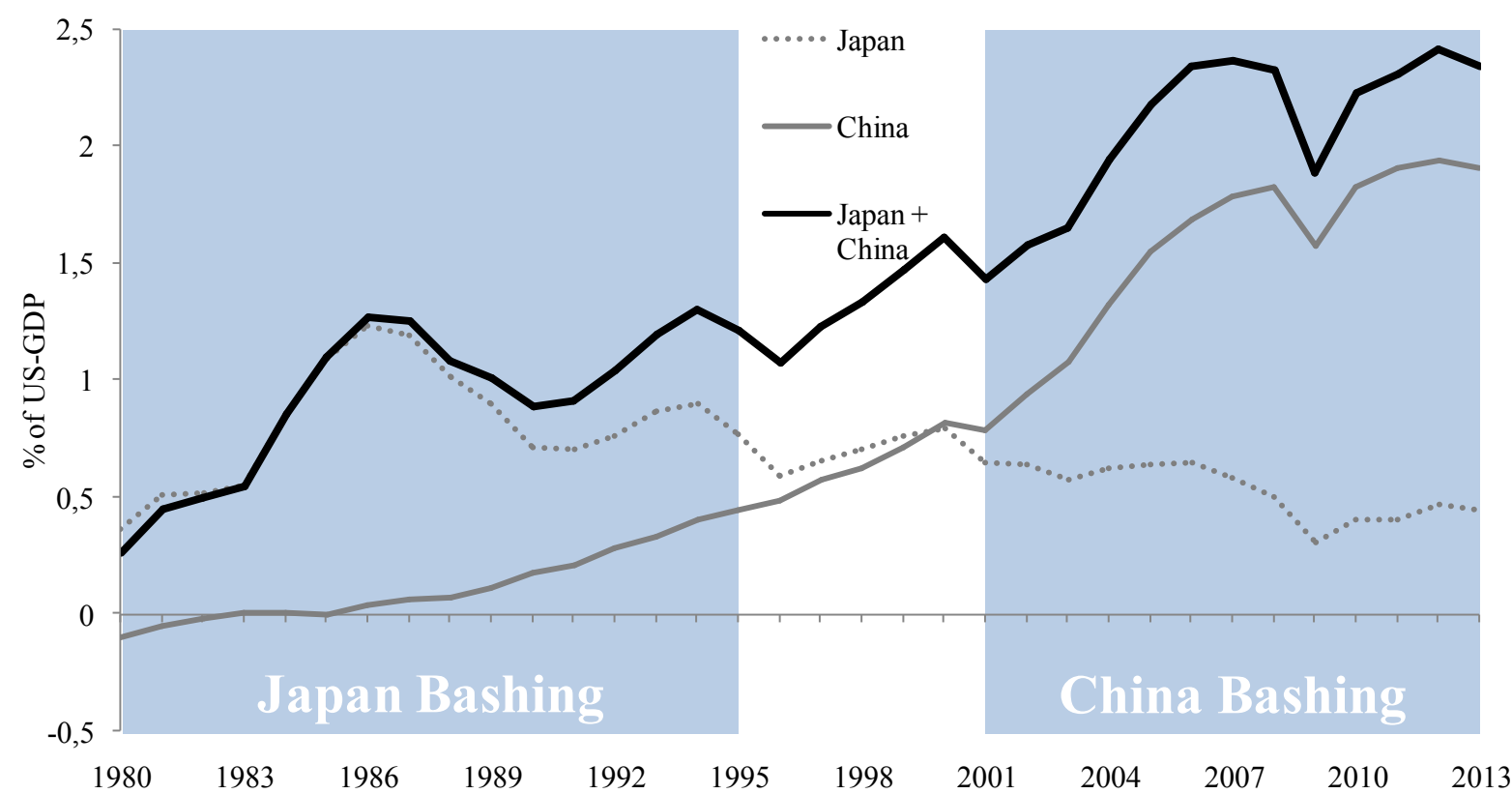

bilateral trade balance of China and Japan with the US as percent of U.S. GDP

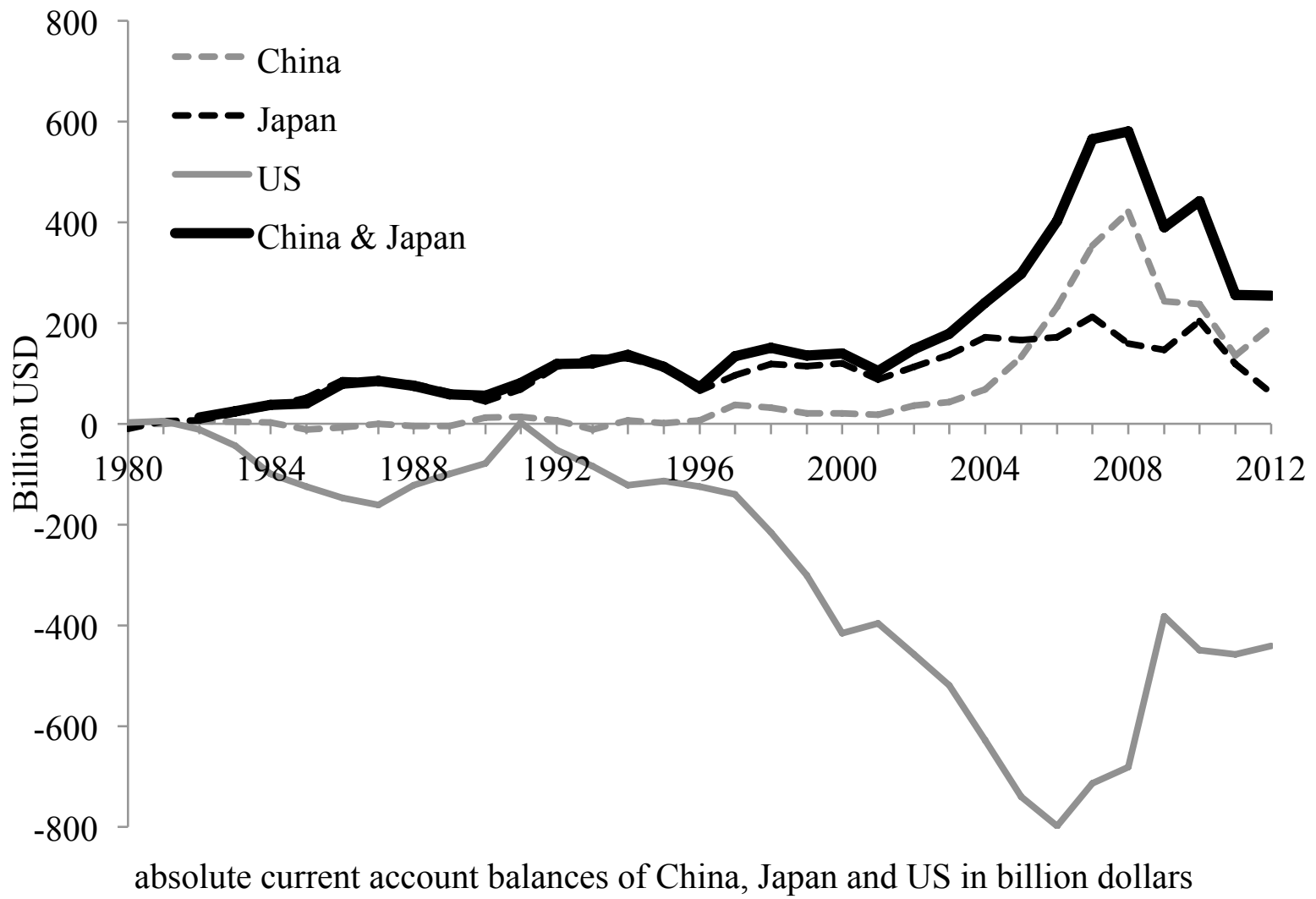

Source: IMF: Direction of Trade Statistics and World Economic Outlook. 
However, as a side effect of monetary cum fiscal expansion, exuberance in Japan's stock and real estate markets emerged [Schnabl 2013]. When, in December 1989, the so-called Japanese bubble economy began to burst, the level of Japan's current account surplus more or less returned to the pre-1985 level as imports fell (figure 1). But the yen continued to appreciate up to April 1995. With this double whammy - bursting bubbles in the stock and real estate markets plus further yen appreciation - a lasting recession set in with a falling price level and current account surplus that persisted up through 2012. ${ }^{1}$ From this long-term perspective, yen appreciation had no systematic impact on Japan's net current-account position (figure 1) but did severely depress the economy.

In 2013, the launching of the "Abenomics" program of monetary expansion triggered a sharp depreciation from 80 to about 100 yen per dollar. This seems to have corrected the previous yen overvaluation by restoring purchasing power parity [McKinnon and Liu, 2013]. It is too early to assess whether the Abenomics will have any lasting stimulating effect beyond the one-time fillip to Japanese exporters coming from the discrete devaluation. Further yen depreciations would bring back serious American Japan bashing to appreciate the yen. Japanese neighboring countries, Korea or many smaller East Asian economies, might follow the Japanese depreciation thereby increasing the pressure on China to slow down or even stop its gradual appreciation.

\section{b. The Stable Yuan/Dollar Rate as a Macroeconomic Anchor}

The decline in Japanese economic activity and rapid Chinese growth saw the gradual shift of economic hegemony in East Asia from Japan to China. As China gradually assumed the role of the largest and most dynamic East Asian economy with its rising current account surplus surpassing Japan's since 2000 (figure 1), Japan bashing was succeeded by China bashing. A large current account surplus of the fast-growing Chinese economy was accompanied by growing criticism from China's trading partners. It was alleged that China was deliberately pursuing a mercantilist trade strategy of undervaluing the renminbi by keeping its nominal exchange rate pegged to the dollar despite China's rising trade surplus. A substantial

\footnotetext{
Following the Fukushima nuclear power plant hazard and the shutdown of all Japanese nuclear power plants, energy imports soared thereby reducing the current account surplus. Nevertheless the Japanese current account remains positive and is projected by the IMF to remain positive in the upcoming years.
} 
appreciation of the renminbi against the dollar was claimed to be necessary to correct the transPacific trade imbalance [Cline and Williamson 2012, Bergsten 2013]. But as we have shown, that claim is likely to be wrong.

Two main differences separate China and Japan in responding to American pressure to appreciate. First, after the Nixon shock of August 1971, when the U.S. forced all the industrial countries to abandon their postwar dollar pegs to appreciate, Japan allowed wide fluctuations in the yen/dollar exchange rate. In contrast, after China's system of multiple exchange rates was unified in 1994 - and currency restrictions on importing and exporting were eliminated so that China achieved formal current account convertibility by 1996 - the renminbi remained fairly tightly pegged to the dollar in order to anchor China's internal price level.

Second, Japan was more prone to give in to American pressure to let the yen appreciate, whereas the Chinese government more strongly resisted foreign interference in making national economic policy. However, the PBC did eventually relent, if only moderately. In July 2005 the Chinese monetary authorities responded to the external pressure and loosened the peg: they allowed for a gradual nominal appreciation of the RMB against the dollar averaging about 5 percent per year up to July 2008 (figure 2). ${ }^{2}$ When the global crisis of 2008 induced a sharp 40 percent fall in China's exports, the PBC stopped appreciating. The restored dollar peg enhanced the effectiveness of China's huge countercyclical expansion of bank credit in 2008-09 to stimulate domestic spending to offset the collapse in exports [McKinnon and Schnabl 2009]. Once the great international crisis seemed to be contained, the Chinese central bank returned to its modest upward crawling peg against the dollar, which persists — very weakly — up to the present 6.1 yuan/dollar in early $2014 .^{3}$ But this modest upward crawl, at percentage rates comparable to interest differentials, accentuates hot money inflows.

For macroeconomic stability in East Asia, exchange rate stability of the renminbi against the dollar remains crucial. Back in the 1980s and 1990s, when Japan was the dominant Asian trader,

2 The renminbi appreciated versus by the dollar by $2.5 \%$ in $2005,3.3 \%$ in $2006,6.8 \%$ in $2007,6.5 \%$ in $2008,0.0 \%$ in $2009,3.3 \%$ in $2010,4.5 \%$ in $2011,1.0 \%$ in 2012 and $2.8 \%$ in 2013.

3 For a detailed survey of five phases of the development of the renminbi against the dollar see McKinnon and Schnabl [2012]. 
large fluctuations of the yen against dollar caused fast-changing competitiveness of Japanese exports to the U.S. and its East Asian neighboring countries, which were largely dollar peggers. Yen/dollar fluctuations were an important source of macroeconomic instability for Japan's smaller East Asian neighbors [Kwan 2001, McKinnon and Schnabl 2003]. In contrast, today when China has become the largest Asian trader, the more stable yuan/dollar peg has evolved into a macroeconomic stabilizer for China itself, the rest of East Asia, and the global economy [McKinnon and Schnabl 2012]. How can such claims be justified?

Figure 2: The Yuan/Dollar Exchange Rate, 1980-2013

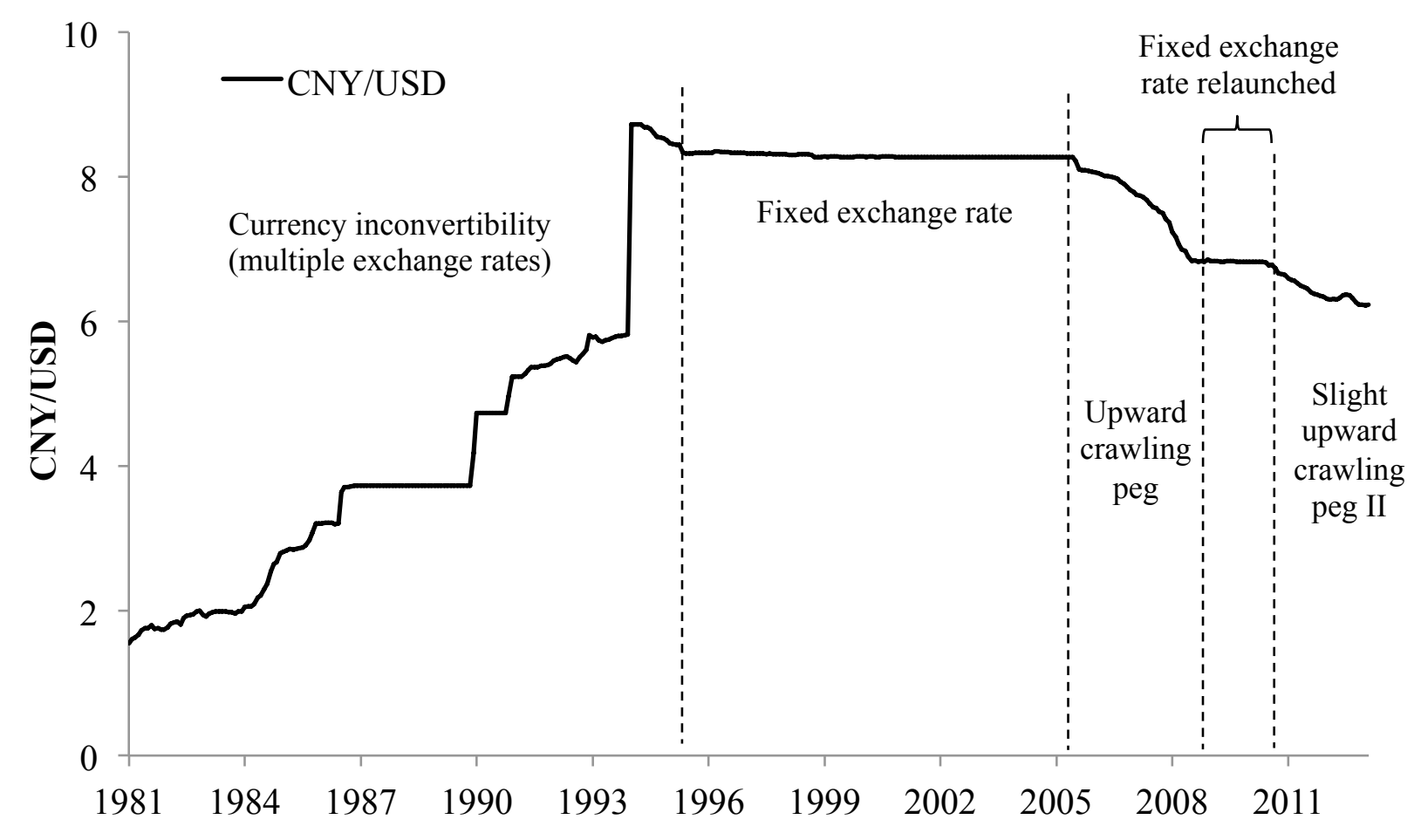

Source: IMF.

First, China's 1994 move toward a fixed exchange rate became the anchor of domestic monetary policy for reducing high and volatile inflation and therefore stabilizing real growth at a high level during the economic catch-up process. Figure 3 shows how the adoption of the dollar peg in 1994, and the elimination of currency restrictions on exports and imports so as to achieve current-account convertibility by 1996, were followed (with a two-year lag) by a decline in 
consumer price inflation to a sustainably low level. Growth in real GDP stabilized around 7 to 8 percent per year after having been very volatile from the 1980s into the first half of the 1990s.

Figure 3: Chinese Real GDP Growth and Consumer Price Inflation, 1980-2013

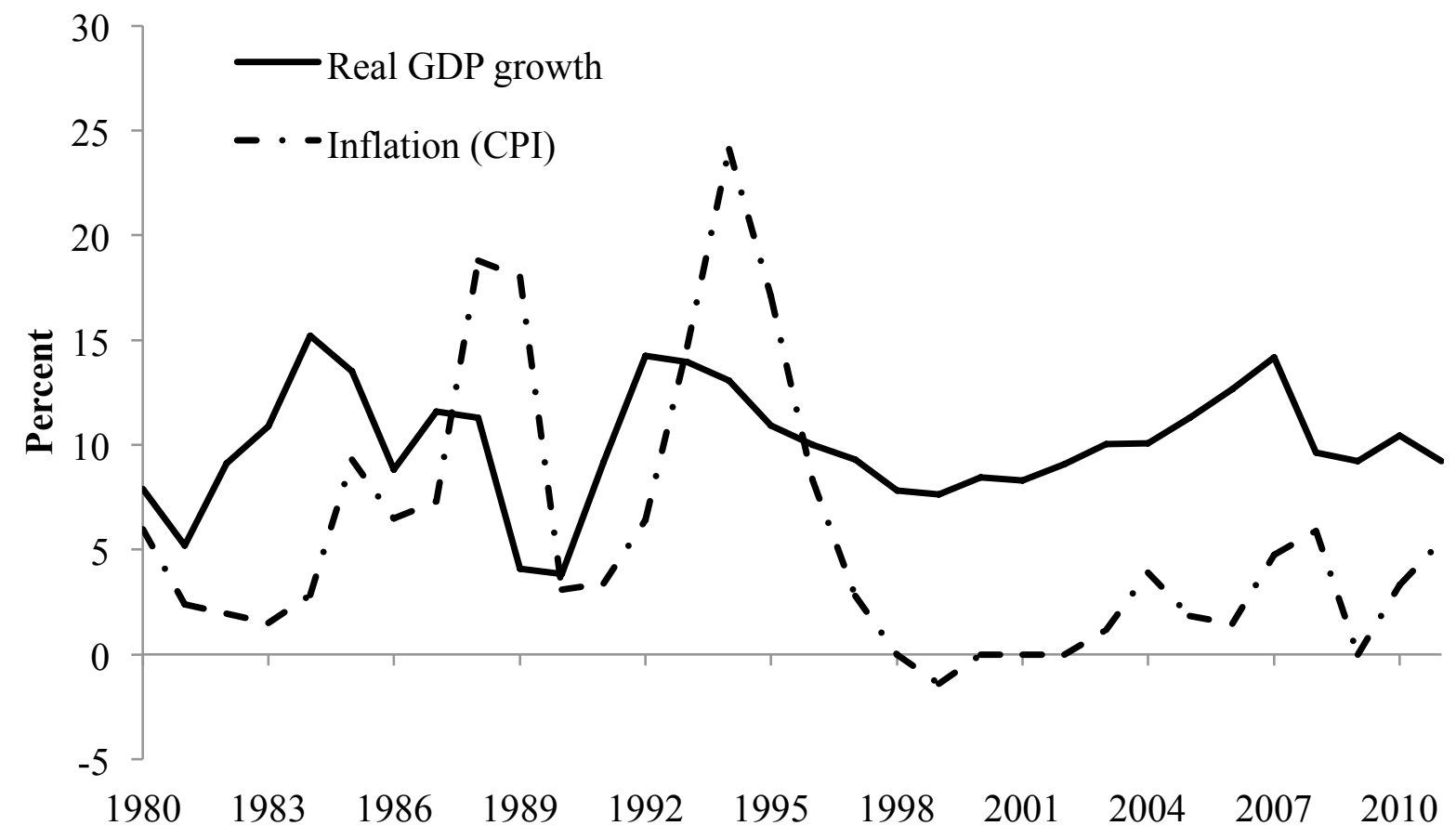

Source: IMF.

Second, China's dollar peg and stable domestic growth rate tended to smooth regional business cycles for East Asia as a whole. East Asia had become one of the most economically integrated regions in the world, with intraregional trade covering roughly half of overall international trade. Traditionally, the East Asian countries maintained more or less tight dollar pegs, with the Japanese yen being the only freely floating currency in the region. Thus, in the 1980s and 1990s, fluctuations of the Japanese yen against the dollar induced a collective business cycle in the smaller East Asian economies [Kwan 2001]. In periods when the yen appreciated against the dollar, it also appreciated against the currencies of all smaller East Asian countries because they were dollar peggers. Their exports became more competitive against their Japanese counterparts, including in Japan's home market. This effect was magnified as Japanese firms responded to the high yen by stepping up their investments in other Asian countries-largely the branch plants of 
Japanese manufacturers. Because of yen appreciation, production shifted from high-cost Japan to create boom conditions in other East Asia [Kwan 2001, McKinnon and Schnabl 2003].

Conversely, in periods when the yen weakened against the dollar, the incentive to export from the smaller East Asian economies-and direct investment from Japan-slumped in favor of Japanese firms producing at home. The most extreme example was when the yen depreciated against the dollar in 1996-98 (figure 4) and so contributed to the great Asian crisis of 1997-98, when Korea, Thailand, Malaysia, Philippines, and Indonesia were forced to depreciate their currencies. The primary reason for the crisis was that these five economies had grossly over borrowed in the form of "hot money", ${ }^{4}$ which was suddenly and contagiously withdrawn. However, the prior depreciation of the yen was a contributing factor to the virulence of the crisis in these smaller East Asian economies. China, and its stable yuan/dollar rate, remained largely unaffected - as shown in figure 4 .

Figure 4: Yen and Yuan against the Dollar, 1980-2013

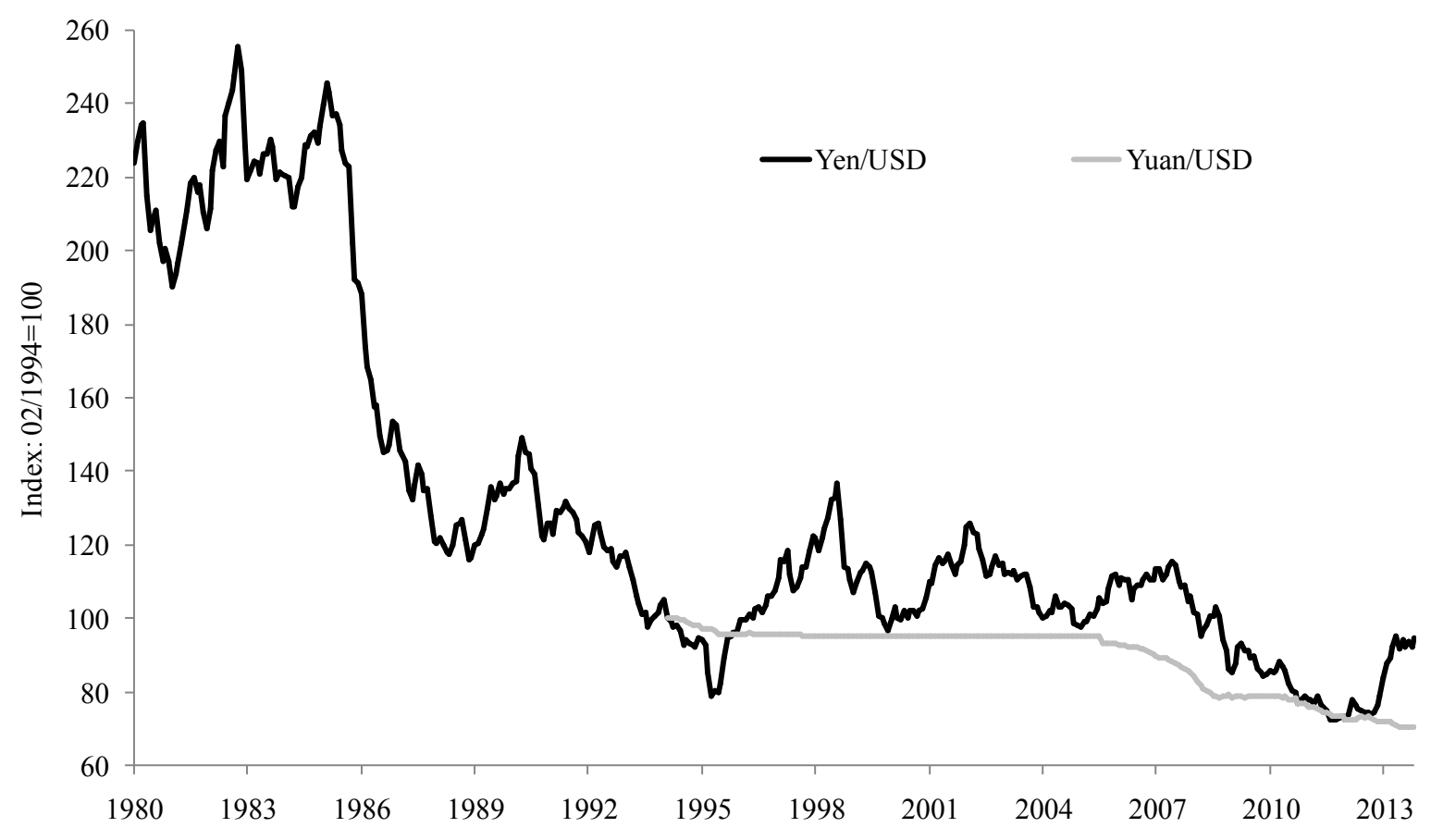

Source: IMF.

4 Concerning the role of Japanese low policies for economic exuberance in the smaller Souteast-Asian countries see Schnabl (2013). 
By 2013, China had become the new economic giant in East Asia with GDP and intra-East Asian exports almost twice as high as Japan's. This stimulated East Asian intraregional production networks and growth more generally for two reasons: (1) China's high growth was broadly based across all major industries, thereby generating growing but differentiated export opportunities for the enterprises in the smaller East Asian economies and Japan; and (2) China evolved into an export platform, where imports of inputs from other East Asian economies were assembled and exported as finished products to the U.S. and other industrialized countries.

Figure 5: East Asian Exchange Rates against the Dollar, 1990-2013

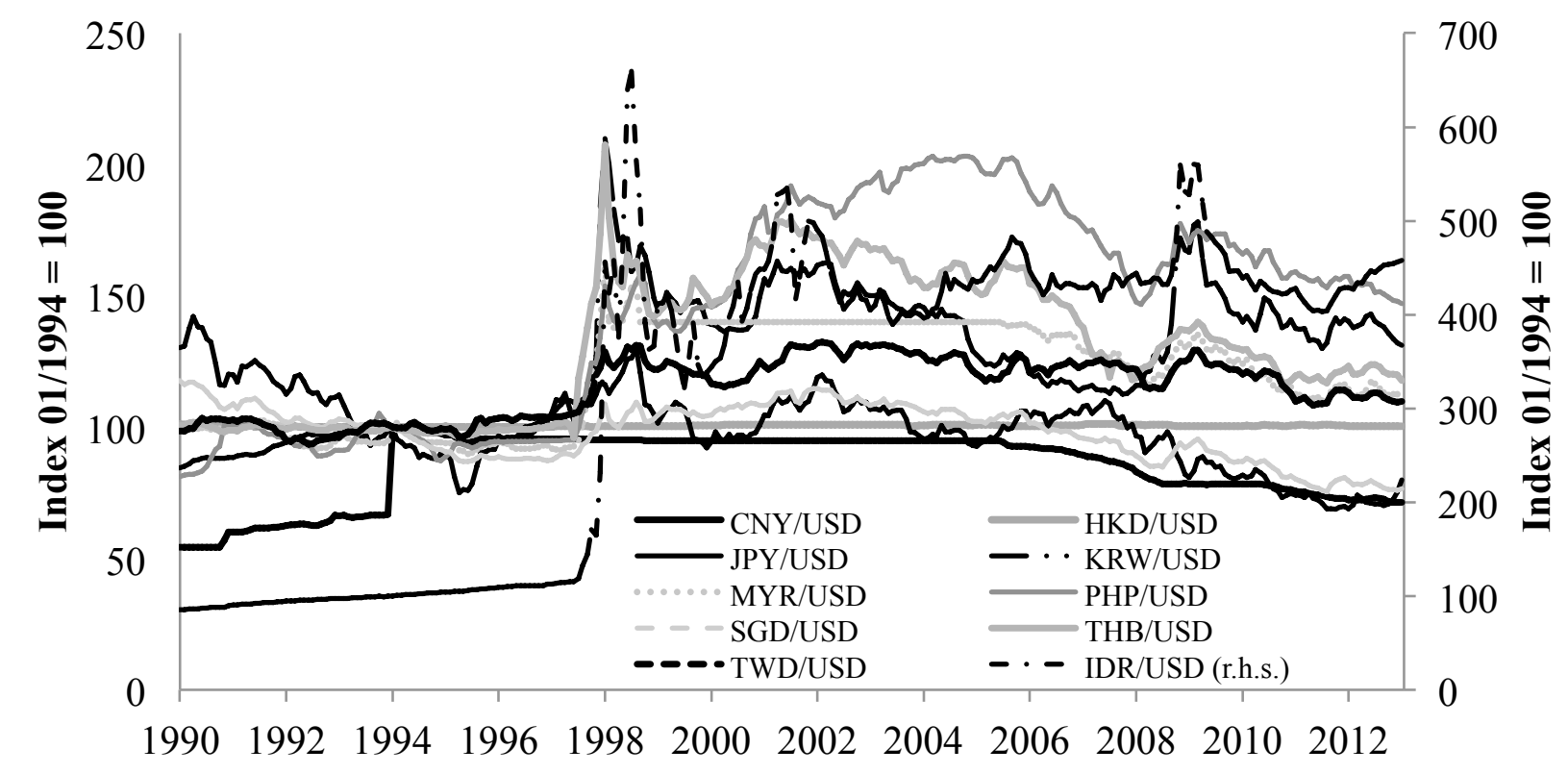

Source: IMF.

Second, China's macroeconomic and exchange rate stability smoothed out business cycles for East Asia as a whole-unlike the earlier cyclical effects imparted by fluctuations in the yen/dollar rate when Japan dominated the East Asian economy. Reflecting China's increasing dominance, figure 5 shows the resulting East Asian exchange rate arrangement, which can be seen as an amalgam of the still prevailing informal dollar standard in East Asia and the growing weight of the China market for other East Asian exports. Movements in the dollar exchange rates of ten East Asian currencies are positively correlated. The dollar continues to be the anchor and intervention currency for the whole group as a large share of international and intraregional trade 
and capital flows is invoiced in dollars. The smaller East Asian countries stabilize their exchange rate against the Chinese renminbi by aligning their dollar pegs with China's.

Figure 5 shows that most East Asian currencies followed, in different degrees, the gradual appreciation path of the Chinese renminbi versus the dollar. It stands out that since 1994 all East Asian countries including Japan have kept their exchange rates versus the RMB on the depreciation side, thereby increasing their competitiveness vis-'a-vis their large buoyant neighbor. The upshot of this two-stage strategy is that the smaller East Asian countries still stabilize their exchange rates against the dollar, but with increasing weight given to renminbi and intraregional exchange rate stability.

Third, the (still) dynamic and stable growth performance of China and its smaller East Asian neighbors has become a stability hub in the face of global macroeconomic shocks - such as the U.S. subprime mortgage crisis in 2008-09, and the European sovereign debt crisis starting in 2011. During these global banking crises, China succeeded in maintaining high economic growth. Its still low GDP per capita allows for an energetic catch-up momentum being based on high productivity growth supported by FDI inflows. In addition, a comparatively low level of central government debt allowed for the implementation of large Keynesian countercyclical stimulus packages during crises [McKinnon and Schnabl 2009], which not only helped to sustain domestic economic activity but also imports from other countries such as Japan and the smaller East Asian economies (figure 6).

For the U.S. economy, China plays an important dual stabilizing role: (1) its domestic countercyclical monetary and fiscal expansion during the 2008-09 downturn [McKinnon and Schnabl 2009], and (2) its continual purchases of U.S. Treasury bonds (about half the total purchased by all emerging markets) to help cover the ongoing U.S. fiscal deficit over the last decade- thus forestalling a credit crunch within the U.S. itself [McKinnon 2013, chs 6 and 13). All in all, in the new millennium, China has been a worldwide stabilizing influence in the face of severe "global" macroeconomic shocks from the older industrial countries, and since 2008 a source of growth in the face of continued stagnation in the American, Japanese, and European economies. 
Figure 6: Real Growth in East Asia 10, 1989-2013

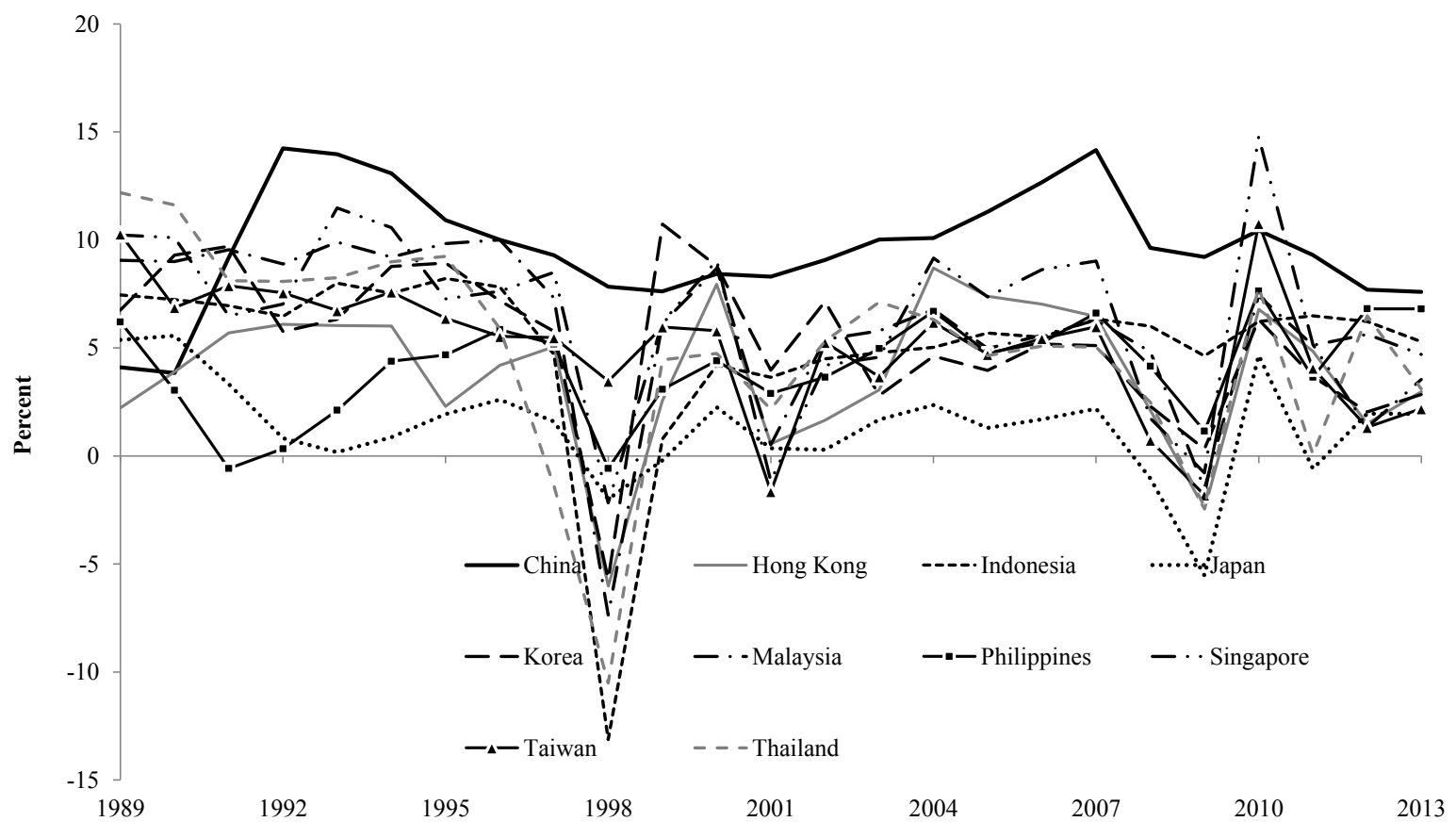

Source: IMF.

\section{China as an Immature International Creditor}

Since 2000, China has been running substantial current account (saving) surpluses with the rest of the world in general, and with the United States in particular (figures 1 and 2). In a well behaved financial system, a mature creditor country would have a "natural" capital outflowboth financial and direct investment - that just offsets or finances its current account (saving) surplus. If the capital outflow and consequent buildup of claims on foreigners is denominated in the currency of the creditor country, it absolves the creditor country's domestic financial institutions - banks, insurance companies, pension funds, and so on-from currency (exchange rate) risk.

In the $19^{\text {th }}$ century, Britain played the role of a mature creditor when the pound sterling was the dominant international vehicle currency. Chronic British current-account (saving) surpluses were financed by private capital outflows denominated in sterling (but ultimately redeemable in gold) from London financial markets to the rest of the world. Similarly in the new millennium, 
Germany, with its large saving (trade surplus), has been the big mature creditor within Europe. German banks lend heavily in euro (now Germany's home currency) particularly to southern European countries. For German banks and insurance companies default risk by borrowers still matters, but currency risk from exchange rate fluctuations is largely absent.

However, China is an immature creditor in the sense that it cannot lend to foreigners in its own currency. The U.S. dollar is still the dominant international money, and China's financial markets are still restricted with interest pegs and capital controls. These prevent Chinese financial markets from becoming liquid enough to lend internationally in RMB. Thus China finances its trade surpluses either by building up liquid dollar claims on foreigners - mainly in the form of official exchange reserves (figure 7) cumulating to US\$3.8 trillion in early 2014, or by making illiquid foreign direct investments - often associated with government-sponsored aid programs to countries producing primary products as inputs for Chinese industry.

Figure 7: China: Balance of Payments, 1990-2013

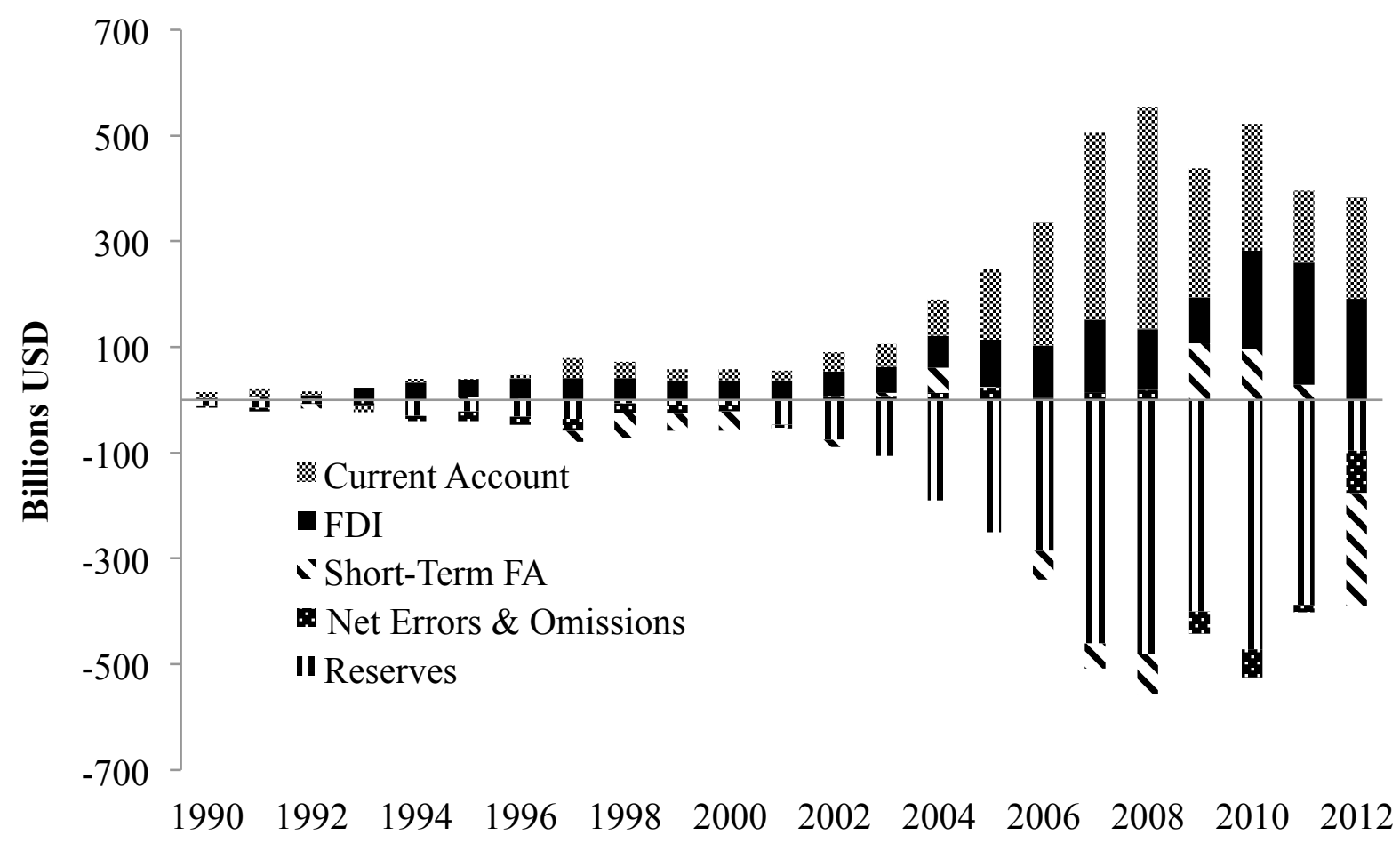

Source: IMF. 
By 2013, China's investments in (loans to) less developed countries to finance railways, oil and gas pipelines, ports, power plants, and so on, have been massive. The gross assets of China's Export-Import Bank are greater than those of the World Bank. While the latter hopes to be paid back in convertible currencies and faces continual defaults, the Chinese government is content to take quasi barter claims on imports of industrial raw materials - oil, iron ore, copper, and so on - made possible by its infrastructure investments throughout Africa, Latin America, and Central Asia. Because of the Chinese engineering presence, with Chinese work crews to extract and convey these minerals, there has been little overt "default" up to the present writing.

Chinese overseas direct investments abroad are largely under government control and they can't suddenly be liquidated and returned to China as hot money. In contrast, Chinese private holdings of liquid dollar assets abroad would be a potential hot money threat if they weren't so small.

Notice that China, as an immature creditor with a saving surplus - but which does not lend abroad in its own currency-cannot float its exchange rate. If the Chinese government completely withdrew from the foreign exchange market, China's current account (saving) surplus would be uncovered in the sense that Chinese banks or other financial institutions would (could) not provide a matching liquid capital outflow. In our dollar centric world, Chinese banks do not lend abroad in RMB, nor do foreigners issue many RMB-denominated bonds in Shanghai.

In principle, Chinese banks could build up dollar claims on foreigners, but this would create a risky currency mismatch because their deposit base is in RMB. So they don't. Thus the PBC steps in at the margin to provide the necessary finance for the current account surplus by building up liquid dollar claims, largely U.S. Treasury Bonds, on foreigners. As a government entity, the PBC acts as if it doesn't care about currency risk but does care about exchange-rate stability. Otherwise, if the PBC simply withdrew from the market, the RMB would float upward indefinitely with no well-defined equilibrium for the yuan/dollar exchange rate. 


\section{a. Capital Market Maturity and RMB Internationalization}

For China, with its saving surplus, to become a mature international creditor, the renminbi must become internationalized to generate sufficient private capital outflows denominated in RMB. What does this imply? Following Hong Kong, with no capital controls on foreign exchange transactions or domestic interest rate restrictions, Chinese banks and insurance companies could make RMB loans directly to foreign corporations and governments to eliminate exchange rate risk. Similarly, international bonds denominated in RMB could be sold in Shanghai or other Chinese cities with major financial markets. Foreigners could participate as depositors as well as borrowers in RMB. China's private financial sector could (would) then automatically finance its current account surpluses without requiring that the PBC build up official foreign exchange reserves as a vehicle for intermediating international capital outflows.

The Chinese government has taken the first small step to this nirvana of convertibility on capital account by supporting "offshore" renminbi trading_principally in Hong Kong, but also in other financial centers like Singapore, London and Frankfurt. Both Chinese and foreigners can now open RMB deposits in authorized foreign banks - possibly paid for in U.S. dollars - with the proceeds used for making offshore RMB loans or other payments. Although RMB deposits in Hong Kong (upper panel of figure 8) and the issuance of so-called Dim Sum bonds had grown fast, they seem to have leveled out at just 10 percent of overall deposits in Hong Kong.

Similarly, the renminbi transactions on foreign exchange markets remain minute compared to the dollar and euro (lower panel of figure 8). To encourage greater renminbi transacting and reduce exchange risk more generally, the People's Bank of China has initiated swap lines between RMB and the domestic currencies of many foreign central banks (center panel of Figure 8) to reduce the risk for RMB denominated trade obligations. While all well and good, these swap lines remain very small compared to the partners' dollar exchange reserves for balancing international payments at any given (dollar) exchange rate. 


\section{Figure 8: Internationalization of the Renminbi}
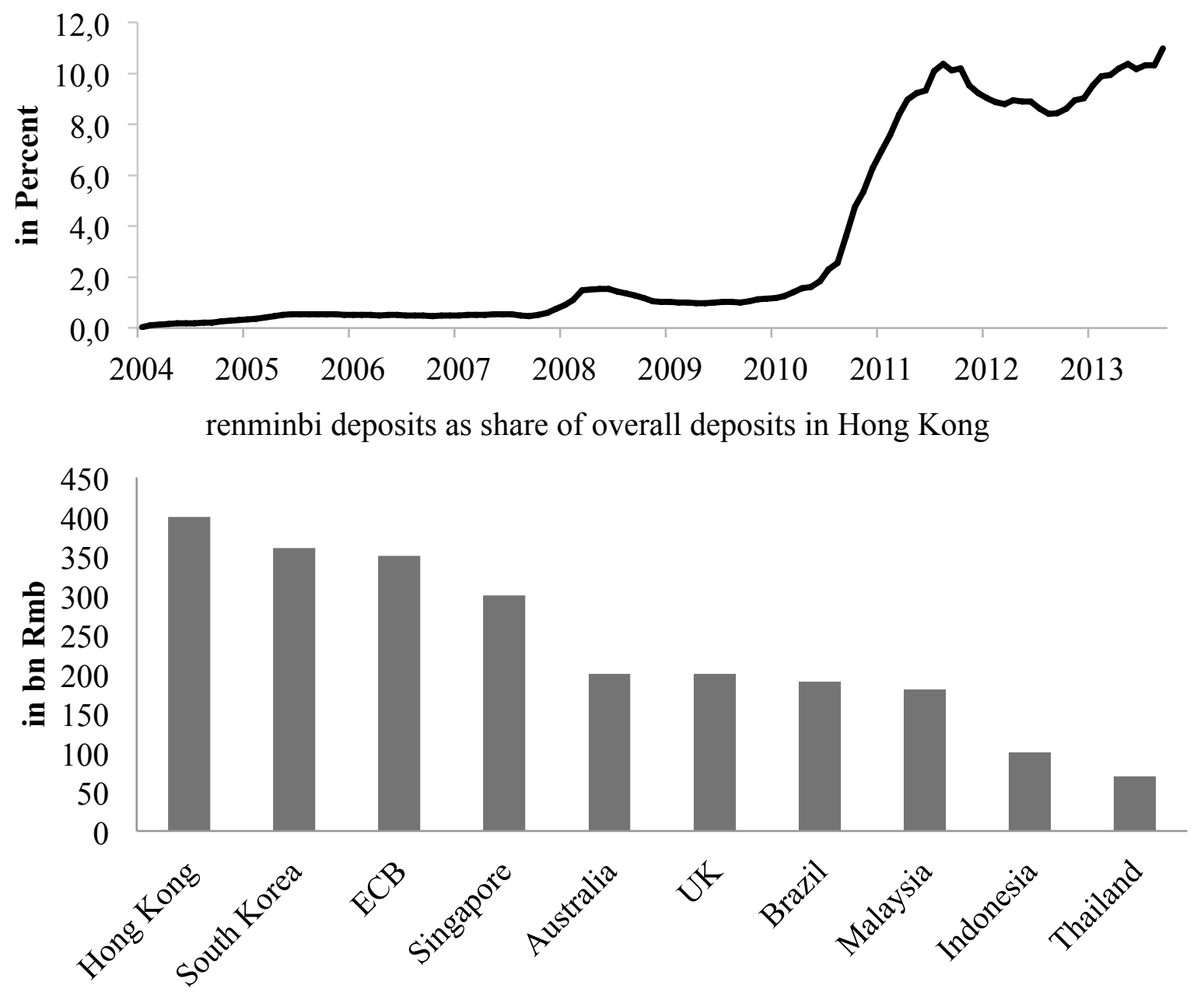

top ten renminbi cross currency swap lines by end 2013

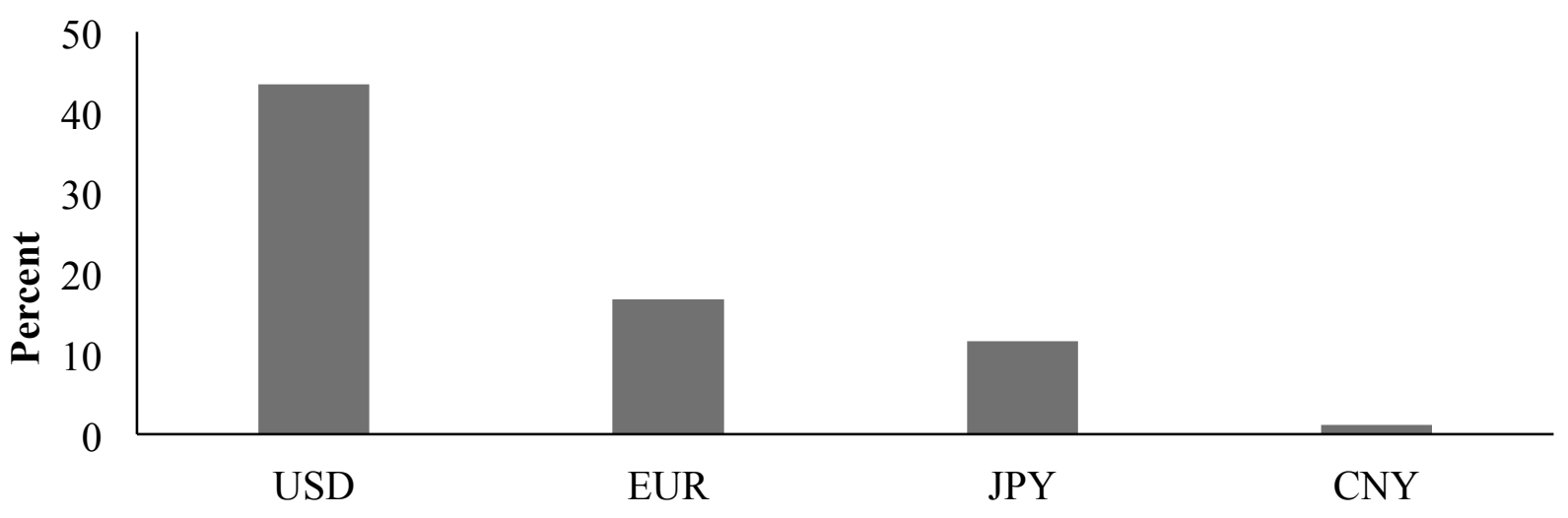

Shares in global foreign exchange market turnover by December 2013

Source: Peoples Bank of China and Bank of International Settlements, Triennial Central Bank Survey of Foreign Exchange and Derivatives Market Activity (2013). 


\section{b. The Proposed Shanghai Pilot Free Trade Zone}

A further step on the road to becoming a mature international credit creditor is the proposal to carve out a "pilot" free trade zone for international financial flows within Shanghai:

"China's Central Bank said it would ease the way for foreign investors to plough money into a highly touted free trade zone in Shanghai and let Chinese residents use the zone as a base for investment overseas by loosening restrictions on investment that apply elsewhere in China. In relaxing some controls, the People's Bank of China made clear that it won't let the free-trade zone become a back door to circumventing long-standing financial-sector restrictions throughout China. A blue-print unveiled on Monday (Dec 2, 2013) essentially sought to erect a wall around the 11-square-mile China (Shanghai) Pilot Free Trade Zone and prevent money from seeping out of the zone into the rest of the country.

(...) Initially the central bank and other financial regulators fought the zone, according to Chinese officials. Regulators and economists argued that walling it off from the rest of the country on financial matters reduced its effectiveness. On the other hand, allowing changes (financial flows) in the zone to quickly spill over into the rest of China would amount to haphazard liberalization, they said." Wall Street Journal, December 3, p. A12

In the context of China's tradition of a gradual approach to liberalization, this pilot zone could be regarded as a preliminary step for the full internationalization of the RMB. But in addition to the reservations quoted above in the Wall Street Journal, there are further downsides.

First, if the Chinese mainland financial market remains tightly regulated, the unregulated financial free trade zone bears the full burden of adjustment to exogenous shocks. Much of the ebb and flow of hot money into China would come through this narrow corridor, thus making the Pilot Free Trade Zone very volatile (Le Chatelier's Principle).

Second, the position of Shanghai would be artificially enhanced relative to other Chinese cities. Financiers and entrepreneurs would flock to Shanghai to exploit the more liberal rules on international transacting. And within Shanghai itself they would crowd into the 11 square-mile Pilot Zone on one pretext or another. So there would be geographical distortions within China, and further imbalances in factor incomes - although Shanghai is already relatively rich. 


\section{c. The Zero Interest Rate Constraint on Renminbi Internationalization}

The dissent on the desirability of the Pilot Free Trade Zone in Shanghai is well grounded. Offshore renminbi, or RMB deposits in the Shanghai Zone, must be prevented from being converted into onshore RMB deposits in commercial banks located in China itself. Otherwise, this would create paths where holders of dollars could buy RMB without restraint and thus subvert the Chinese currency restrictions on bringing "hot" money into China, i.e. converting dollars into RMB. Interest rates in the industrial world are far too low for China to tolerate.

\section{Figure 9: Fragmented Interest Rate Structure in China and US}

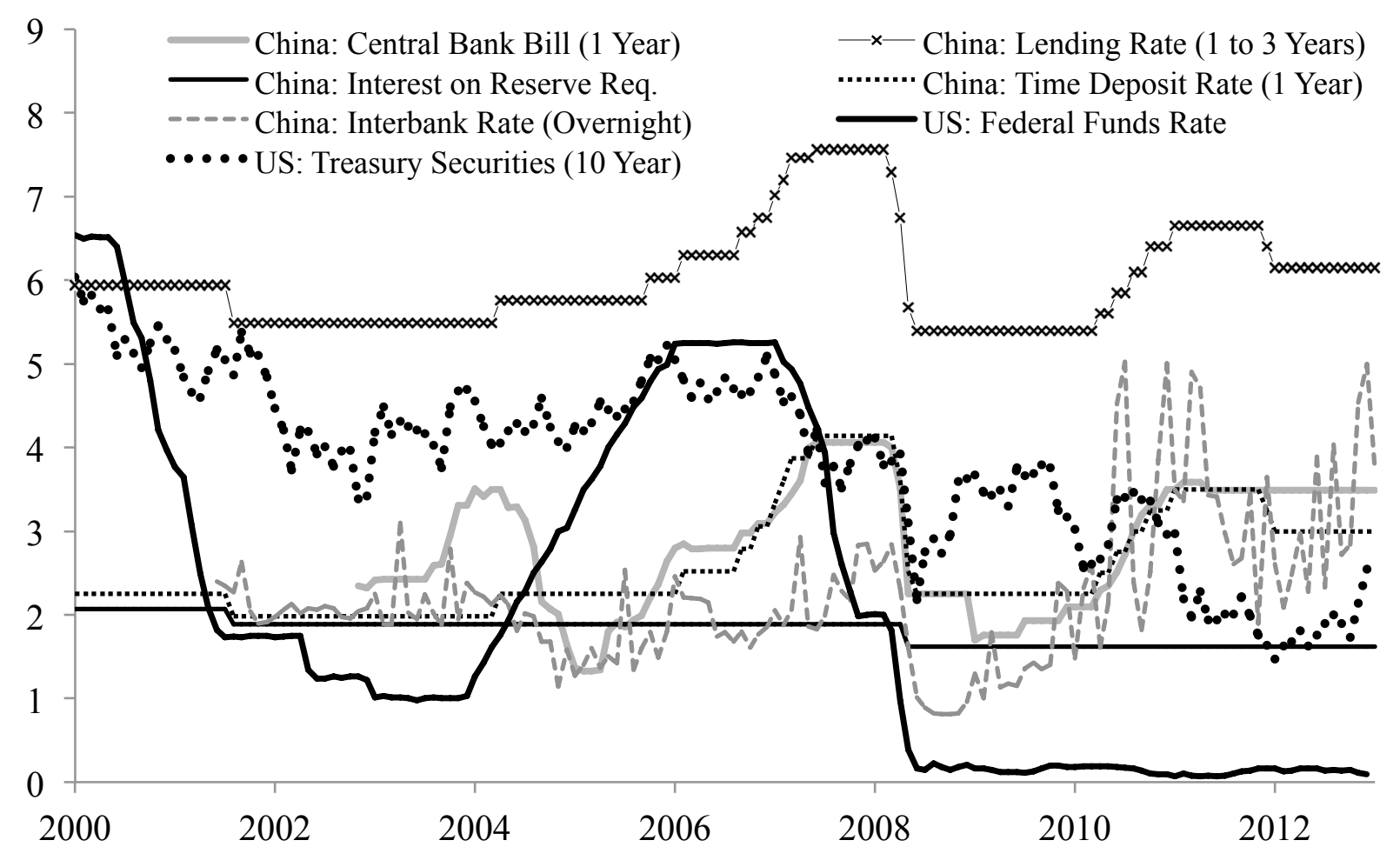

Source: People's Bank of China, US Federal Reserve.

Since December 2008, the U.S. Federal Reserve has set its short-term policy rates - in the interbank market - near zero (figure 9) followed by near-zero interest rates on U.S. Treasury Bills and LIBOR (London interbank offer rate on dollars). At longer term, the Fed since 2008 has employed three rounds of quantitative easing (QE) by buying long-term U.S bonds. In 2013, QE3 bond purchases proceeded at the incredibly high rate of $\$ 85$ billion per month — although 
they have tapered (reduced) these purchases somewhat in 2014. Until doubts emerged about whether quantitative easing would end, the Fed succeeded in driving the 10-year Treasury Bond rate down to 2 percent in early 2013 (figure 9).

Central banks for the euro area (ECB), the Bank of England (BOE), and the Bank of Japan (BOJ) have pursued (are pursuing) similar policies. At the short end of the bond-market maturity structure, each has set it policy rate near zero-and engages in heavy quantitative easing by large purchases of long-term government bonds or other long-term instruments, such as mortgagebacked securities. The balance sheets of all four major central banks were massively expanded (relative to their GDPs), as shown in figure 10.

These abnormally low interest rates in the large industrialized countries, together with China bashing to appreciate the RMB, impose an external constraint on China's ability to liberalize its domestic capital market. For example, suppose that the average yield on safe RMB assets in China is 4 percent (figure 9). If the PBC unwisely continued to let the RMB crawl gently upward at about 3 percent per year, in the short run a dollar-based investor could earn a return of 7 percent if he is able to circumvent Chinese capital controls and purchase RMB. This is a huge incentive for carry traders to bring hot money into China.

With China's very high GDP growth and perhaps excessive investment, its natural interest rates are much higher than in the sluggish, no-growth mature industrial economies. So if restraints on foreign financial inflows are weakened, as they would be with the formation of the proposed Shanghai free trade zone, the deluge of hot money inflows into China would force the PBC to intervene even more massively to buy dollars in the foreign exchanges to stabilize the yuan/dollar rate - and increase the pressure to allow domestic interest rates to fall toward international levels.

The interest rate disparity problem affects emerging markets beyond just China. If, for instance, among a group of emerging market economies, one would decide to move toward a free float with greater exchange appreciation, whereas the others continue to peg their currencies to the dollar (or the euro), then expected appreciation gains from investment in the freely floating 
currency would be the largest. A run into the now freely floating currency could cause an uncontrolled indeterminate upward spiral as experienced by Japan following the Plaza Agreement — and into Brazil with a doubling of the dollar value of the real from 2003 to 2007.

\section{Figure 10: Monetary Base as Percent of GDP}

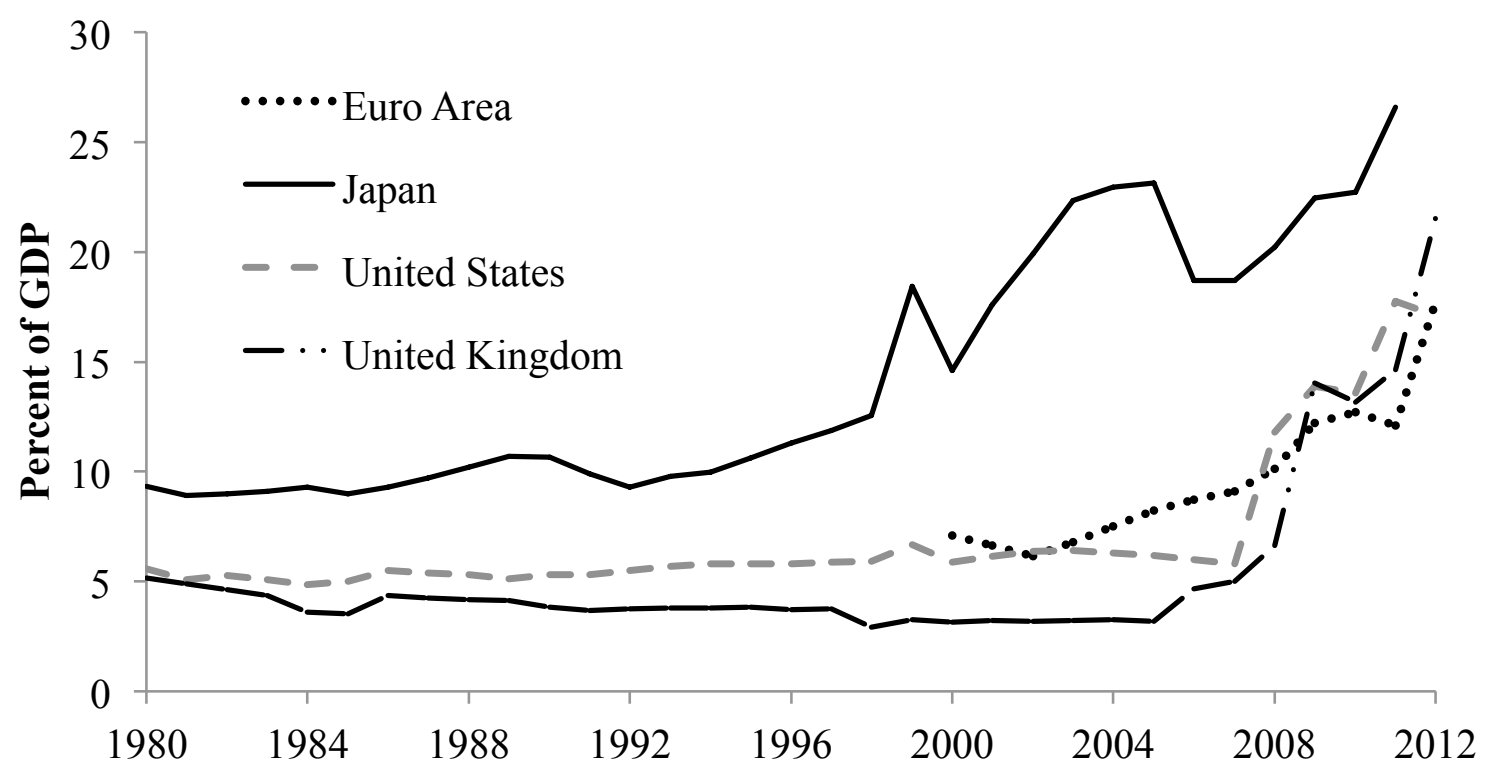

Source: IMF International Financial Statistics and World Economic Outlook, European Central Bank and Eurostat.

For China to float the renminbi, eliminate capital controls and follow the industrial countries into a near zero interest rate trap would be detrimental. As the monetary absorption capacity of (comparatively) underdeveloped goods and capital markets is low, China would be threatened by fast-rising inflationary pressure and asset price bubbles, in particular in the already heavily overheated real estate market. Therefore, although China generally welcomes foreign direct investment, the People's Bank of China has to restrict purely financial inflows because of the ultra-low interest rates prevailing in the international economy. ${ }^{5}$ The continued liberalization of offshore trading in RMB and in the Shanghai Pilot Zone ultimately cannot be prevented by

5 Despite capital controls hot money gets around the exchange controls by posing as foreign direct investment or export receipts, or in a myriad of other ways (McKinnon and Schnabl 2012) 
regulation from spilling over into the rest of the country and making capital controls more difficult to enforce. This limits RMB internationalization. Because of unduly low foreign interest rates, financial liberalization in China has to remain incomplete. China must remain an immature creditor and the RMB cannot (should not) be fully "internationalized".

\section{Financial Repression}

Because China's transition to the first-best status of a mature international creditor with open financial markets is blocked, Chinese financial authorities must live in the world of the second best, where its domestic financial system remains repressed. What can we then say about China's optimal exchange rate and monetary policies in this imperfect world economy? China bashing to the contrary, a stable yuan/dollar rate is the correct strategy for a second-best world, as any move towards a RMB appreciation would attract additional speculative capital inflows.

\section{a. Exchange Rate Stabilization and Sterilization}

We have seen that China cannot float its exchange rate because of its immature creditor status. Because of the very low interest rate level in the large industrial countries, there is a tendency for financial capital, hot money, to flow the wrong way - inwards - instead of outwards to finance China's trade surplus. If the Peoples Bank of China (PBC) tried to abandon exchange controls and official intervention in order to "float" the yuan/dollar rate, the RMB would just spiral upward without limit because of the positive unfinanced gap between saving and investment. Indeed, the gap could widen (the trade surplus become bigger) because domestic investment would slump in the face of an appreciating RMB. In effect, the yuan/dollar rate would become indeterminate.

To prevent this indeterminacy, the PBC just sets the central yuan/dollar rate in the morning of every trading day close to the rate prevailing at the end of the previous day. It maintains a narrow band of about 1 percent between bid and ask prices throughout the day to ensure that the ordinary business of making international payments devolves to commercial banks [McKinnon 1979]. Over the medium term, the PBC intervenes heavily in foreign exchange markets and so 
as to allow the central rate to move very little. China's continuing accumulation of official foreign exchange reserves and creation of base money from exchange rate stabilization would itself be very inflationary. To prevent the domestic money supply and bank credit from expanding excessively, the PBC (like other central banks in emerging markets) must find ways to sterilize this excess creation of base money.

There are two principal sterilization techniques [Löffler, Schnabl, Schobert 2013]. (1) Nonmarket-based sterilization is when the central bank raises reserve requirements on commercial bank deposits so that less bank credit is extended for any given increase in base money. This has the disadvantage of restricting commercial banks as financial intermediaries, and may encourage unregulated "shadow" banking. (2) Market-based sterilization is where the central bank sells domestic-currency bonds - often created by the central bank - to the commercial banks and other financial entities to reduce their excess liquidity. This has the disadvantage of putting upward pressure on open-market domestic interest rates-thus inducing even greater inflows of hot money.

In practice, the People's Bank of China has resorted to both techniques for sterilizing foreign exchange intervention - albeit with a rising tendency to use non-market-based instruments as shown in the upper panel of figure 11, based on the balance sheet of the People's Bank of China. On the asset side (with positive sign) the impressive expansion is mainly driven by foreign reserve accumulation. On the liability side (with negative sign), commercial bank depositsmainly required reserves — and central bank bonds accrue.

Because market-based sterilization operations-i.e. liquidity absorption at prevailing market interest rates - are costly and would attract additional undesired capital inflows, liquidity absorption in emerging markets increasingly takes place below prevailing market interest rates (Löffler, Schnabl, Schobert 2013). Such non-market-based sterilization operations have two benefits. First, sterilization costs for central banks are kept low, as the remuneration rate for required reserves is usually held below market rates. In China the remuneration rate for required reserves has been kept below two percent (lower panel of Figure 11) and even below the 
inflation rate. Second, new capital inflows are minimized, if the sterilization costs are shifted by the banking sector to depositors in form of lower deposit rates.

In China, the rapid official accumulation of foreign exchange has triggered mostly non-marketbased sterilization operations in form of coercive central bank bond sales to, and increasingly high reserve requirements on, commercial banks. In the lower panel of Figure 11, as an indication for non-market-based sterilization both the remuneration rate for required reserves as well as the central bank bond yield are below the money market rate (interbank offered rate), which can be assumed to be mainly market determined. In addition, the PBC maintains ceilings on domestic deposit and loan rates of interest to further dampen inflows of hot money.

\section{b. Externally Imposed Financial Repression, and Shadow Banking}

The upshot is financial repression, a concept developed by McKinnon [1973] and Shaw [1973]. It describes a collection of economic policies-domestic bank regulation, high reserve requirements, interest rate ceilings, price inflation, and foreign exchange restrictions on capital flight-imposed by governments to extract cheaper loans from the domestic financial systemprimarily banks. In the 1950s and 1960s, financial repression was rampant in Latin America and much of Asia, as manifested in negative real interest rates. At that time, it was internally imposed by national governments aiming to extract cheap finance for themselves-often to cover fiscal deficits.

The modern form of financial repression in developing countries (emerging markets) is, however, externally imposed. Under the world dollar standard, if the center country sets its short rates near zero and puts downward pressure on long rates through quantitative easing, the countries on the dollar standard's periphery are forced to operate with interest rates that are unduly low. Otherwise, they would lose monetary control as foreign hot money poured in and the recipient emerging market government would be forced intervene to prevent its exchange rate from appreciating precipitously. Because central banks in the other principal industrial countries - the ECB, BOE, and $\mathrm{BOJ}$ - have followed the Fed into the zero interest rate trap, central banks in emerging markets (with naturally higher interest rates) are even more pressured 
to use capital controls on inflows and repressive bank regulations to lower their domestic deposit rates of interest [Löffler, Schnabl, Schobert 2013].

Figure 11: Peoples Bank of China Balance Sheet and Policy Rates, 2000-2013

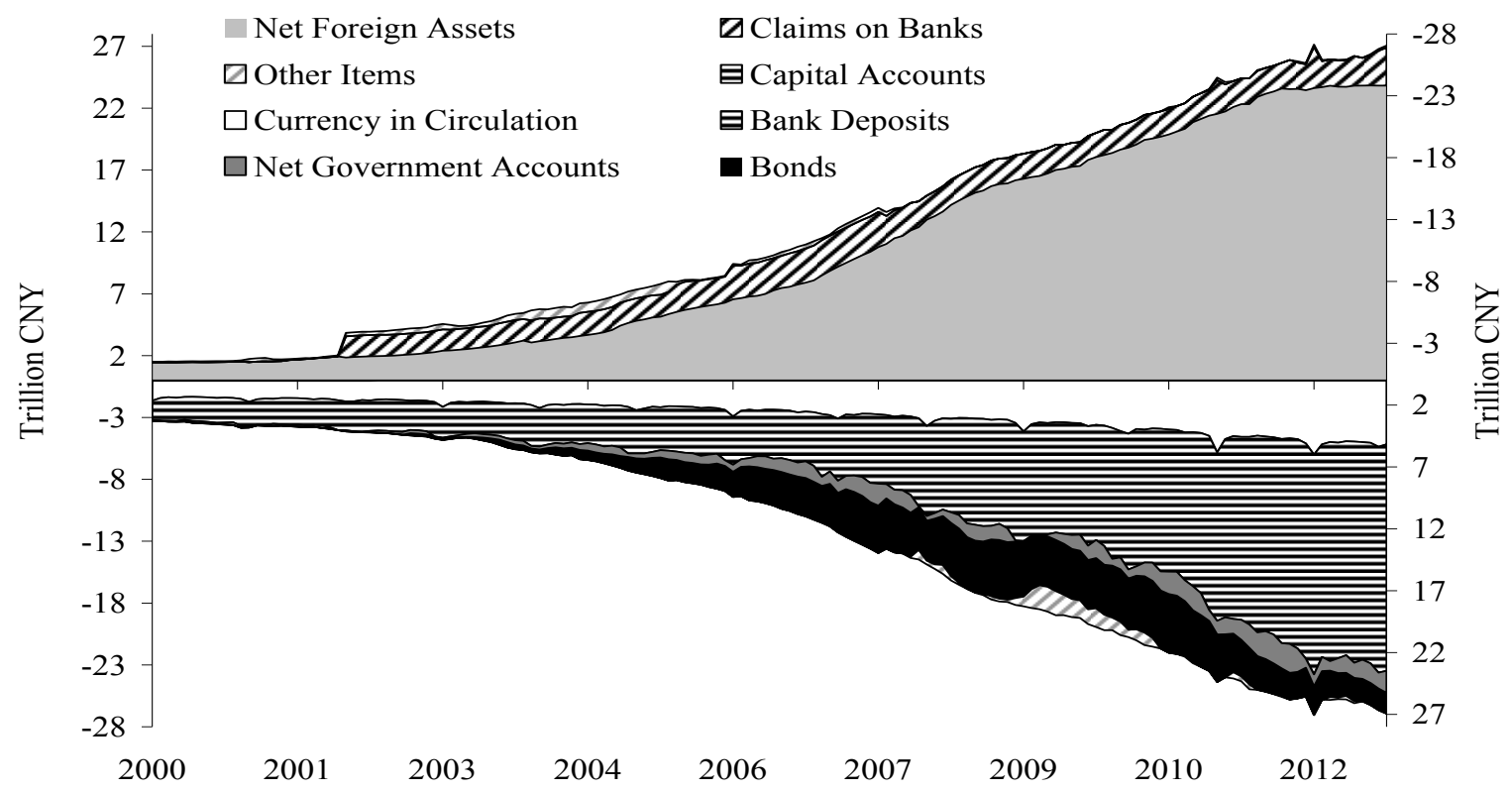

Peoples Bank of China Balance Sheet

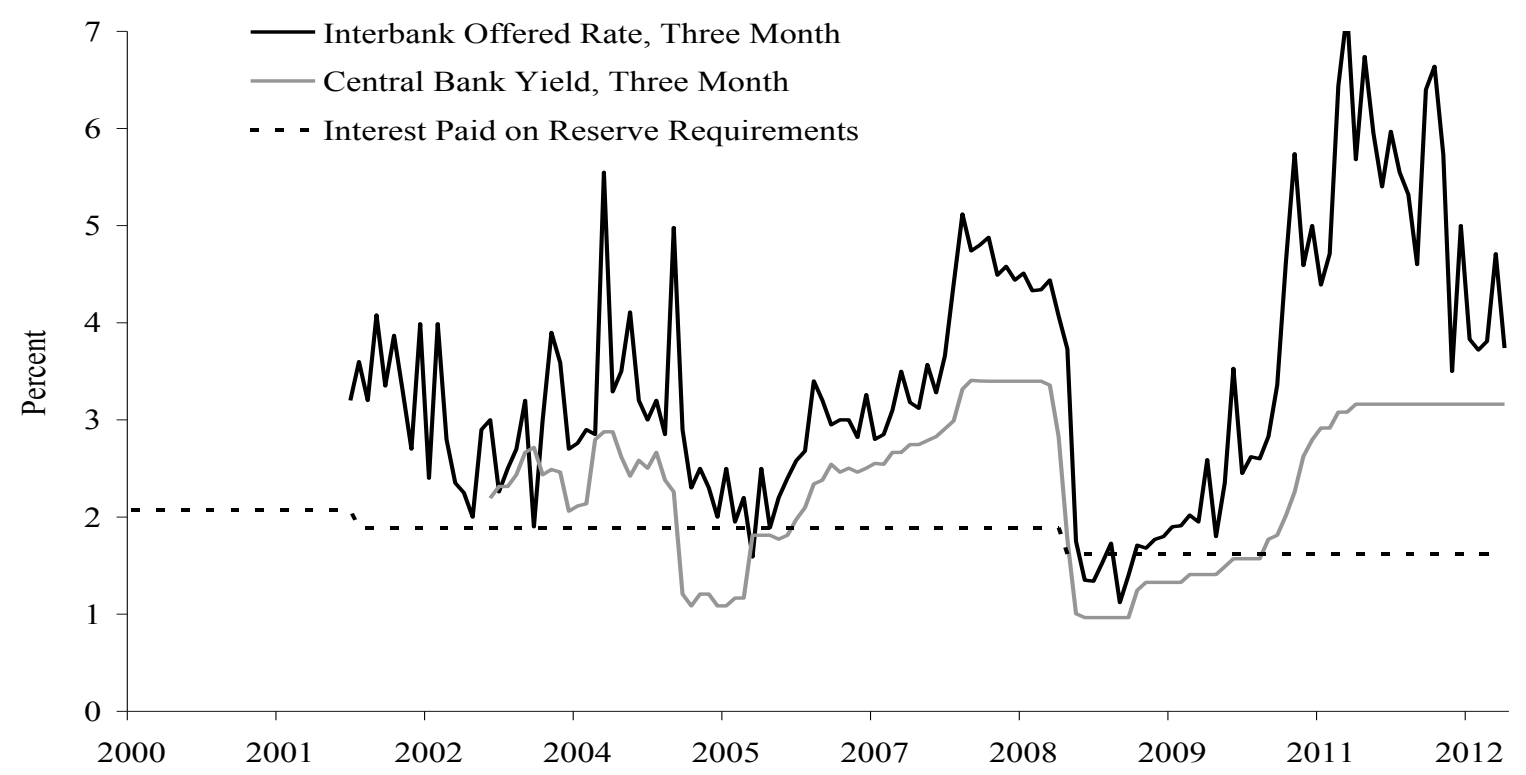

Source: IMF. Method break from IMF Balance of Payments and International Investment Position Manual 5 to Balance of Payments and International Investment Position Manual 6 in 2005. 
In China's case, the government responds with controls on capital inflows and ceilings on domestic deposit rates of interest-forms of financial repression. Domestic depositors are penalized by a low nominal interest rate hardly different from the rate of inflation (figure 9) and favored borrowers get unduly cheap credit. At the low bank lending rates about of 6.5 percent, borrowers have excess demand for domestic bank credit, which allows banks to tilt credit allocation to the large state-owned enterprises [McKinnon and Schnabl 2012]. Because small and medium sized enterprises (SMEs) are risky and fairly expensive to service per renminbi lent, China's banks become unwilling to lend to SMEs at the low, controlled interest rates. So banks choose to lend to the safest possibly borrowers, which, in China, happen to be state owned enterprises (SOEs) [Bai 2013]. But more than a political phenomenon orchestrated by domestic state-owned banks, cheap credit for SOEs is largely an economic consequence of externally imposed financial repression.

Shadow banking is a further consequence of the Chinese government being more or less forced to keep domestic interest rates too low for, and also having to impose high reserve requirements on, the formal banking sector. Unsurprisingly, the banks respond by sponsoring "trust" funds or other informal affiliates that are off the banks' books. They guide their best (richest?) customers to deposit at much higher deposit rates of interest in the trust funds which then make highinterest riskier loans to generate interest revenue. The good side is that the trust funds might lend more to small and medium sized enterprises (SMEs). The downside is that they are unregulated and could precipitate a contagious set of bankruptcies.

How to deal with the shadow banks is a long story for another time. But suffices to note here that the explosive of growth of shadow banks in China is, in large measure, because "world" interest rates are too low-and so force a form of financial repression on China.

\section{Adjusting International Competitiveness: Wages versus Exchange Rates}

If a stable yuan/dollar rate is devoutly to be wished on financial grounds, what can ameliorate the trade imbalance between the two countries? For a creditor country like China with surplus saving, we have shown that exchange rate appreciation has only an ambiguous effect on its net trade balance. Thus fixing the yuan/dollar rate does not constitute any loss in policy flexibility. 
Instead, wage growth can be an effective tool for balancing international competitiveness with some fall in China's trade surplus by promoting increased household consumption.

\section{a. The Negative Exchange Rate Risk Premium in Wage Growth}

The evolution of domestic wages and prices for countries in the economic catch-up process can be described with the help the Scandinavian model of wage adjustment in a fast-growing open economy like Sweden was in the 1950s and 1960s [Lindbeck 1979], and China is today. It assumes that the prices of domestic traded goods are determined by foreign prices through the lens of the exchange rate. Domestic inflation in the traded goods sector $\hat{p}_{T}^{D}$ is inflation in world markets $\hat{p}_{T}^{W}$ adjusted by exchange rate changes $\hat{e}$, where $e$ is domestic currency per dollar so that $\hat{e}>0$ represents depreciation of the domestic currency. Thus

$\hat{p}_{T}^{D}=\hat{p}_{T}^{W}+\hat{e}$

The model assumes that trade unions are able to negotiate nominal wage increases $\hat{w}_{T}^{D}$, that compensate them for the price increases of tradable goods plus awarding themselves fully for productivity increases $\hat{q}_{T}^{D}$.

$\hat{w}_{T}^{D}=\hat{q}_{T}^{D}+\hat{p}_{T}^{D}$

Both assumptions imply that wages in the domestic traded goods sector of an open economy are determined by expectations concerning domestic productivity increases, changes in world market prices, and exchange rate changes. Lindbeck (1979) further assumed that the Scandinavian trade unions would not bid for wage increases above traded-goods inflation and productivity increases because this would erode the competitiveness of the national export industries and put employment in the export sector at risk.

Augmenting the Lindbeck model, McKinnon and Schnabl [2006] assume a negative risk premium on wages, $\psi$, linked to exchange rate uncertainty. In a highly competitive export- 
oriented economy like China's, employers face uncertainty about future movements in the exchange rate when negotiating today's wage contracts. If after agreeing on a given wage level with employees, the renminbi were to unexpectedly appreciate and so reduce export revenues, the employer would face painful losses and possible bankruptcy. Being capital constrained and risk averse, employers will reduce wage offers exante by $\psi$ below what they would have paid with no exchange rate uncertainty.

$\hat{w}_{T}^{D}=E\left(\hat{q}_{T}^{D}\right)+E\left(\hat{p}_{T}^{W}\right)+E(\hat{e})+\psi$, where $\psi<0$

When wage and productivity growth are very high (Chinese wages continue to grow 10 to 15 percent or more per year) in a catch-up economy, a downward bias in wage setting $(\psi)$ can quickly cumulate to low and falling unit labor costs relative to more mature trading partnerssuch as the United States-whose absolute productivity and wage levels remain much higher. Unit labor costs would fall in China relative to the United States, and such a productivity imbalance would intensify China bashing on the yuan/dollar exchange rate by the U.S..

In summary, China bashing to appreciate the RMB can actually slow money wage growth in China for two related reasons. (1) Expected exchange appreciation, $E(\hat{e})$, induces employers to reduce wage settlements, and (2) Uncertainty about the future of the yuan/dollar rate further reduces their willingness to offer higher wages, as per our negative risk premium $\psi$. [McKinnon 2013, ch 10]. In contrast, under the credibly fixed exchange rates of the Bretton Woods system, Swedish trade unions could negotiate wage increases close to productivity increases plus a very small mark-up for traded-goods inflation.

In the modern Chinese labor market, labor unions are less influential than in Sweden in the 1950s and 1960s. However, given the scarcity of skilled and semi-skilled labor, and now the fairly complete absorption of unskilled rural labor into the industrial labor force, Chinese employers are willing to bid aggressively for workers so that wage increases tend to reflect high productivity growth, and the trend of wage growth in all sectors is highly correlated (Figure 12). But the whole process of naturally adjusting high wage growth would come to an end if employers were threatened with large exchange rate appreciation(s). 
Again, Japan, since the break down of the Bretton Woods fixed exchange rate system in 1971, provides a natural experiment for showing a negative mark-up on wage increases caused by great but uncertain exchange rate appreciation [McKinnon and Schnabl 2006]. After having the industrial world's most rapid growth in output in the 1950s, 1960s, up to about 1973, and money wage growth more than twice as great as in the slower-growing U.S., Japanese money wage growth slumped in 1975-76 to become less than that in the United States [McKinnon 2013, Ch. 10] — and has remained less, even negative, to the present day.

\section{Figure 12: China: Real Wages by Sector, 1994-2012}

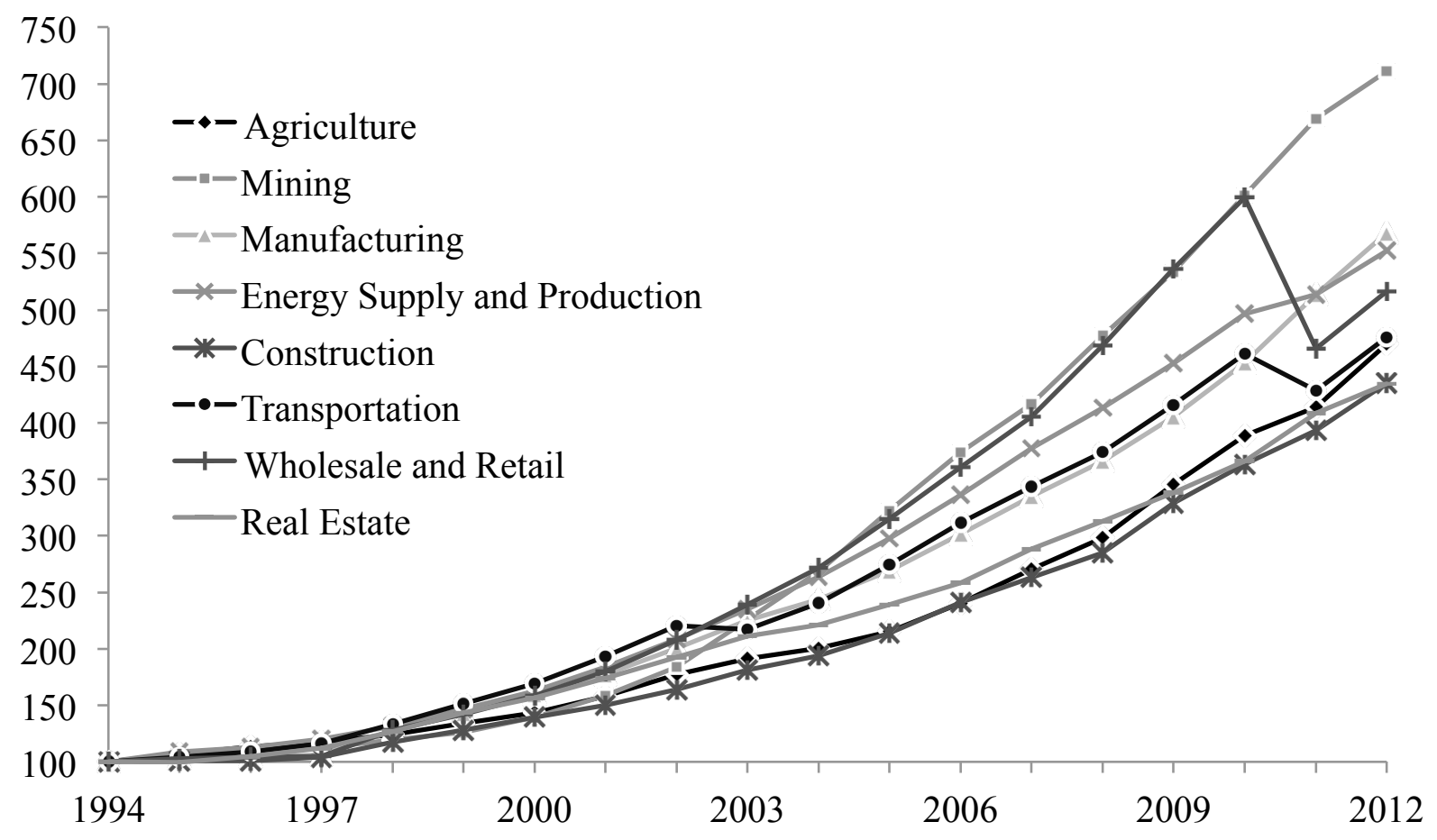

Source: National Bureau of Statistics, China, via Datastream.

\section{b. Wage Increases to Balance the Trade Surplus}

Having high wage growth match high productivity growth so that China's unit labor costs converge to those in the United States is a necessary condition for a more balanced trade relationship between the two countries. However, even if unit labor costs in the two counties 
converge mainly because of very high growth in Chinese wages, this is not sufficient to reduce China's net trade surplus with the United States. At a glance at the right hand side of equation (1) would suggest, saving must rise relative to investment in the United States and fall relative to investment in China.

Figure 13 shows that American private consumption is very high, approaching 70 percent of GDP. This is mainly due to a persistently high U.S. fiscal deficit, in large part because of a comparatively low tax level. On the Chinese side, the fall in private consumption from about 55 percent of GDP in 1980 to 35 percent in 2010 is striking, so that fixed gross investment is now bigger than consumption - with the rate of return on investment now low and declining [Bai 2013]. For simplification, let us assume that the world consists of just two countries, China and the United States. Rewrite the accounting identity (1) for the union of the two countries to get

$\mathrm{Y}-\mathrm{A}=\mathrm{CA}=-\mathrm{CA}^{*}=\mathrm{A}^{*}-\mathrm{Y}^{*}$

where $\mathrm{A}$ is Chinese domestic absorption (total spending), $\mathrm{Y}$ is GDP, CA is the current account (trade) surplus - and the starred variables are their U.S. counterparts. Given full employment in both countries, China's current account surplus CA can only be reduced if $\Delta A>0, \Delta \mathrm{A}^{*}<0$, so that $\Delta A=-\Delta \mathrm{A}^{*} .{ }^{6}$ For reducing China's trade surplus, China's increase in absorption must be symmetric with a decrease in absorption in the United States.

In China, an increase in the wage level beyond productivity increases and traded goods inflation would stimulate private consumption, while enterprise saving-which has increasingly contributed to the Chinese surplus of saving over investment-would be reduced. The shrinking gap between saving and investment would reduce China's current account surplus. In the United States, tax increases would curtail private consumption while reducing the fiscal deficit of the Federal government. The increase in aggregate saving would reduce the U.S. current account deficit. These policy adjustments, preferably in tandem, are best based on a fixed yuan/dollar exchange rate [McKinnon, 2013, ch. 9], which would continue to be the backbone of macroeconomic stability in China, East Asia, the U.S., and the world as a whole.

6 Where $\Delta$ is the change operator 
Figure 13: Chinese and US GDP by Expenditure Components
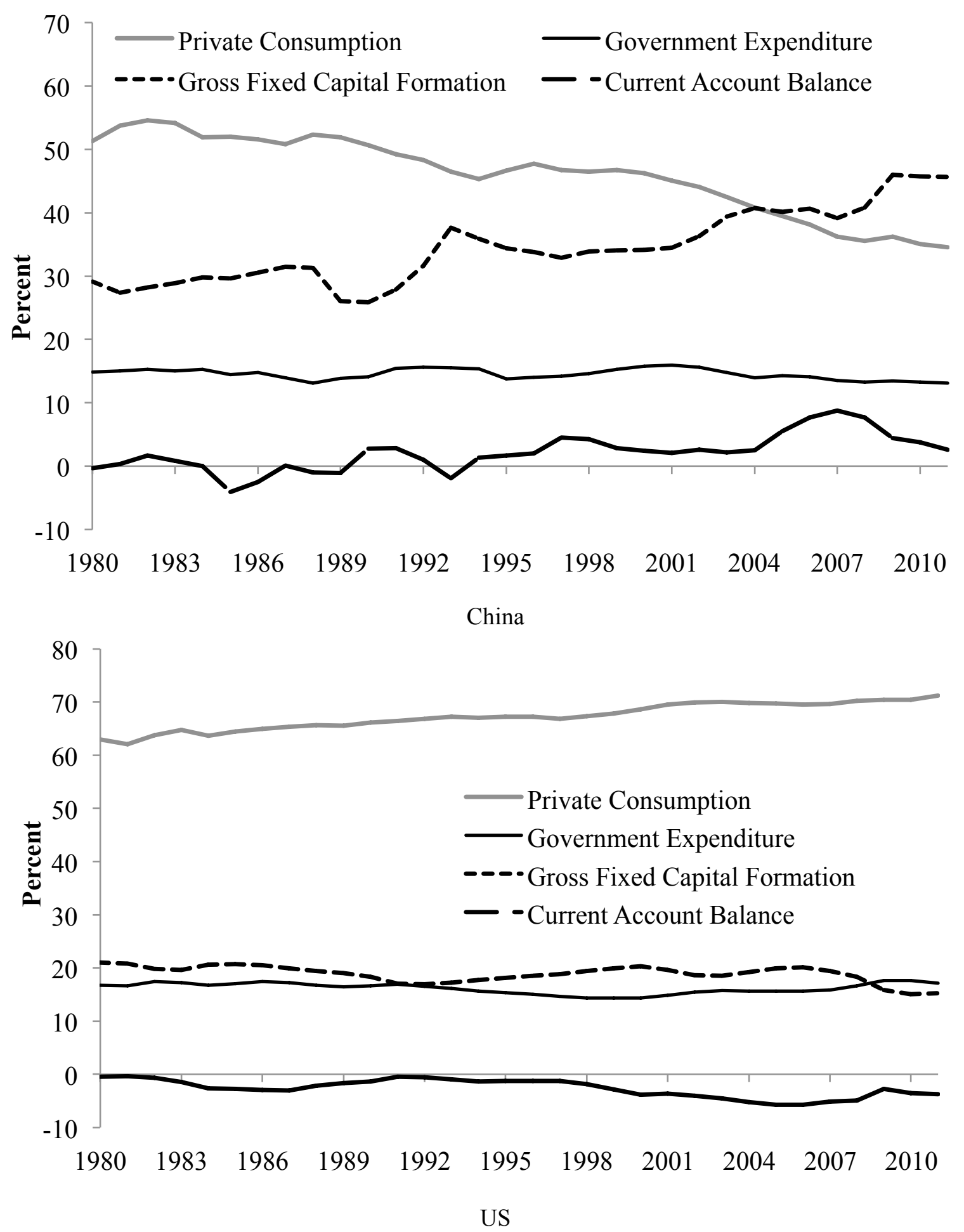

Source: IMF. 


\section{Conclusion: An International Role for the Renminbi?}

The world dollar standard poses a paradox. It has contributed to substantial distortions in the world economy in recent decades. But since 1945, private firms and banks have found it indispensible for reducing the cost of their international transactions. Financial institutions use the dollar as the intermediary currency for clearing international payments, exporters use it as the principal invoice currency, and governments - despite complaining about using a purely national currency as international money_build up huge official dollar reserves. On March 24, 2009, Governor Zhou Xiaochuan of the Peoples Bank of China gave a speech entitled Reform the International Monetary System, in which he argued that the ongoing financial crisis was aggravated by inherent weaknesses of the current international monetary system based on a single national currency - the dollar.

Given that an "international" metallic money based on gold or silver is now out of the question, private markets show a very strong proclivity to use just one national money in international exchange. Governments may show more willingness to diversify official exchange reserves beyond just holding dollar assets, but they don't stray very far from the currency that dominates private international transacting.

At first glance, one would think that a poor monetary performance by the U.S. Federal Reserve Bank would provoke the development of a rival national money as the world's key currency. That would certainly be true if high inflation developed autonomously in the United States; then substitution could be quite rapid, and the renminbi would be a candidate for replacing the dollar - not only in Chinese trade but beyond.

But if poor American monetary management takes the form of near zero interest rates in the U.S. that is followed by the other industrial countries, an emerging market like China is prevented from liberalizing its own financial markets sufficiently for the renminbi to become a contender as the world's key currency. At most, China is limited to encouraging greater invoicing of its own foreign trade in RMB - particularly its exports of more sophisticated manufactures in the mode of mature industrial countries. But purely financial transacting in RMB is best kept resolutely "offshore" to avoid China being inundated by hot money from abroad. 
So what can we conclude for international monetary reform? Although the dollar standard has become thoroughly unloved, it too difficult to replace (McKinnon 2013). The near-zero interest rate trap in the financial markets of mature industrial countries essentially limits the possibilities for successful financial liberalization in China in order to "internationalize" the RMB. Thus China, and possibly other emerging markets, will just have to live in dollar-based world with capital controls and incomplete domestic financial liberalization. (Notice that the U.S., as the center country, cannot itself impose capital controls without the dollar standard collapsing.)

On the bright side, through foreign trade under the dollar standard, China has had the world's fastest growing economy for more than three decades. That could be jeopardized by an unwise lurch to full foreign exchange liberalization on capital account. But liberalization or not, stabilizing the yuan/dollar rate is best for an uncomfortable situation.

\section{References}

Bai, Chong-En (2013): China's Structural Adjustment from the Income Distribution Perspective, Tsinghua University.

Ballantyne, Alexander / Garner, Megan / Wright, Michelle (2013): Developments in Renminbi Internationalisation. Reserve Bank of Australia Bulletin, June Quarter 2013.

Bergsten, Fred 2013: Currency Wars, the Economy of the United States, and Reform of the International Monetary System. Testimony before the Committee on Ways and Means, US House of Representatives, on 16 May .

Cline, William / Williamson, John (2012): Updated Estimates of Fundamental Equilibrium Exchange Rates. Peterson Institute for International Economics, Policy Brief 12-23.

Ito, Takatoshi (2011): The Internationalization of the Renminbi: Opportunities and Pitfalls, Council on Foreign Relations, Washington D.C. 
Kwan, Chi Hung (2001): Yen Bloc: Toward Economic Integration in Asia, Brookings Institution, Washington D.C.

Lindbeck, Assar Ed (1979) Inflation and Unemployment in Open Economies. Amsterdam, NorthHolland.

Löffler, Axel / Schnabl, Gunther / Schobert, Franziska (2013): Limits of Monetary Policy Autonomy and Exchange Rate Flexibility in East Asia. Working Papers on Global Financial Markets 48.

McKinnon, Ronald (1973): Money and Capital in Economic Development, Brookings Institution, Washington D.C.

McKinnon, Ronald (1979): Money in International Exchange: The Convertible Currency System, Oxford University Press, New York

McKinnon, Ronald (2013): The Unloved Dollar Standard. From Bretton Woods to the Rise of China, Oxford. University Press, New York.

McKinnon, Ronald / Ohno, Kenichi (1997): Dollar and Yen: Resolving Economic Conflict Between the United States and Japan, MIT Press, Cambridge, MA.

McKinnon, Ronald / Liu Zhao (2013): Modern Currency Wars: The United States versus Japan, Asian Development Bank Institute Working Paper 437.

McKinnon, Ronald / Schnabl, Gunther (2003): Synchronized Business Cycles in East Asia and Fluctuations in the Yen/Dollar Exchange Rate. The World Economy 26, 8, 1067-1088.

McKinnon, Ronald / Schnabl, Gunther (2004): A Return to Soft Dollar Pegging in East Asia? Mitigating Conflicted Virtue. International Finance 7, 2, 169-201.

McKinnon, Ronald / Schnabl, Gunther (2006): China's Exchange Rate and International Adjustment in Wages, Prices, and Interest Rates: Japan Déjà Vu? CESifo Studies 52, 2, 276303.

McKinnon, Ronald / Schnabl, Gunther (2009): The Case for Stabilizing China's Exchange Rate: Setting the Stage for Fiscal Expansion. China and the World Economy 17, 1, 1-32.

McKinnon, Ronald / Schnabl, Gunther (2012): China and its Dollar Exchange Rate. A Worldwide Stabilizing Influence? The World Economy 35, 6, 667-693.

Meade, James (1951): The Balance of Payments, Oxford University Press, London.

Prasad, Eswar / Ye, Lei (2012): The Renminbi's Role in the Global Monetary System, Brookings. 
Qiao, Hong 2007: Exchange Rates and Trade Balances under the Dollar Standard. Journal of Policy Modeling 29, 765-782.

Shaw, Edward (1973) Financial Deepening in Economic Development Oxford University Press, London

Schnabl, Gunther (2012): The Role of the Chinese Dollar Peg for Macroeconomic Stability in China and the World Economy. In Cheung, Yin-Wong / De Haan Jakob (eds): The Evolving Role of China in the Global Economy, 53-81, MIT Press.

Schnabl, Gunther (2013): The Macroeconomic Challenges of Balance Sheet Recession: Lessons from Japan for Europe. CESifo Working Paper 4249. 